Международная Научно-Исследовательская Федерация «Общественная наука»

\title{
ТЕНДЕНЦИИ РАЗВИТИЯ НАУКИ И ОБРАЗОВАНИЯ
}

\author{
Сборник научных трудов \\ по материалам \\ XXVII международной научной конференции
}

30 июня 2017 г.

ЧАСТЬ 3

JUURNAL.RU

Самара 2017 
УДК 001.1

ББК 60

T34

Тенденции развития науки и образования. Сборник научных трудов, по материалам XXVII международной научно-практической конференции 30 июня 2017 г. Часть 3 Изд. НИЦ «Л-Журнал», 2017. $-52 \mathrm{c}$.

\section{SPLN 001-000001-0161-LJ \\ DOI 10.18411/lj-30-06-2017-3 \\ IDSP 000001:lj-30-06-2017-3}

В сборнике научных трудов собраны материалы из различных областей научных знаний. В данном издании приведены все материалы, которые были присланы на XXVII международную научно-практическую конференцию Тенденции развития науки и образования

Сборник предназначен для научных работников, преподавателей, аспирантов и студентов.

Все материалы, размещенные в сборнике, опубликованы в авторском варианте. Редакция не вносила коррективы в научные статьи. Ответственность за информацию, размещенную в материалах на всеобщее обозрение, несут их авторы.

Информация об опубликованных статьях будет передана в систему Российского индекса научного цитирования (РИНЦ)

Электронная версия сборника доступна на сайте научноиздательского центра «Л-Журнал». Сайт центра: ljournal.ru

УДК 001.1

ББК 60 


\section{Содержание}

РАЗДЕЛ ХІ. ФИЛОЛОГИЯ 5

Акимова Е.В. Термины, относящиеся к понятию «Происхождение

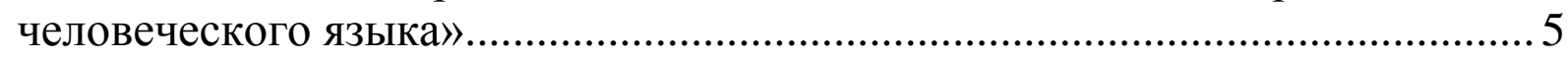

Боброва Е.А., Иванова А.В. Анималистические метафоры в экономических текстах современного английского языка ............................. 7

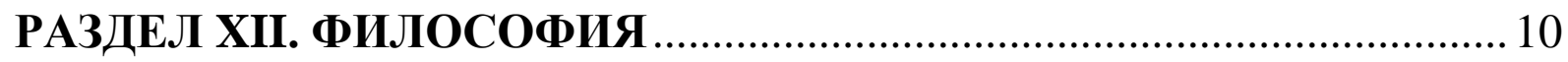

Чумаков В.А. Развитие России и мирового сообщества …….................. 10

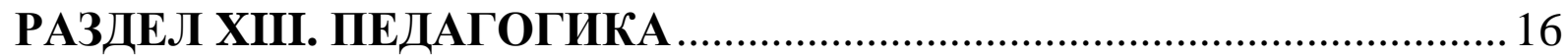

Kalenov A.A. To the issue of the empirical study of the level of formation of subjectivity of senior schoolchildren 16

Алимжанов А.Е. Сохранение физической активности государственных служащих в непрерывном профессиональном образовании ....

Бехтер А.Ю., Волкова К.Ю., Евсеева Е.А. Изучение иностранного языка (английского) при подготовке студентов к инженерной деятельности в неязыковом ВУЗе

Галушко И.Г.,Галушко А.В.,Маркувинас И.В. Педагогическое общение как фактор эмоционального благополучия ребенка.

Галушко И.Г., Галушко А.В., Дураченко А.Д. Характеристика и средства педагогического общения

Галушко И. Г., Лопатюк Е.А., Кустова Д.М. Барьеры в педагогическом общении..... .28

Галушко И. Г., Лопатюк Е.А., Новикова К В. Основные правила педагогического общения с детьми.

Глухова Е.В. Особенности воспитания и образованияобучающихся в социокультурной среде Абхазии . 
Николаева К.В., Стороженко И.И., Федорин С.В. Развитие и совершенствование выносливости у курсантов военно-медицинского вуза с применением тренажерных средств 33

РАЗДЕЛ ХІУ. ПСИХОЛОГИЯ 36

Бехтер А.Ю., Бутров Н.А., Хайров М.А. Необходимость владения иностранным языком для будущих специалистов технического профиля. 36

Щербаков Д.В., Степанов А.Н., Токарева Г.М. Клинико-социальные и психопатологические характеристики психически больных с криминальным и нормосообразным поведением ........................................... 38

РАЗДЕЛ ХУ. СЕЛЬСКОЕ ХОЗЯЙСТВО 42

Басиев С.С., Джиоева Ц.Г., Плиева 3.Я., Басиева А.С., Царикаев 3.А. Роль зеленых удобрений в семеноводстве картофеля.....

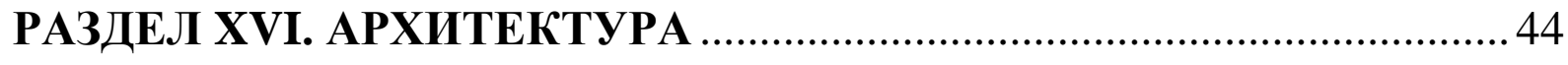

Данилов Д.С. Новые средства производства в архитектуре ........................44

Дергунов С.А., Кулешов И.В., Кутлюк А.Б. Создание логистических систем в дорожном строительстве 46

Диль Н.В. Эко проектирование высотных зданий и сооружений 49 


\section{РАЗДЕЛ ХІ. ФИЛОЛОГИЯ}

\section{Акимова E.B. \\ Термины, относящиеся к понятию «Происхождение человеческого языка»}

Средняя общеобразовательная школа № 6

(Россия, Радужный)

doi: $10.18411 / 1 j-30-06-2017-35$

idsp: 000001:lj-30-06-2017-35

\section{Аннотация}

Статья посвящена терминологии, связанной с происхождением и развитием человеческого языка. Анализу подвергнуты термины из научных трудов А.И.Александрова, И.А. Бодуэна де Куртенэ, В.В. Радлова и других представителей Казанской лингвистической школы.

Ключевые слова: антропология, происхождение видов, членораздельная речь, первобытное образование языка, первобытное образование слова человеческого, звук животного, звук человеческого языка.

«Возникновению и развитию слова человеческого» полностью посвящены две публикации И.А. Бодуэна де Куртенэ. В 1893 г. им написана работа «Человечение языка», в 1905г. - статья «Об одной из сторон постепенного человечения языка в области произношения, в связи с антропологией». С антропологией И.А. Бодуэн де Куртенэ связывает два направления исследований: изучение объективных различий человека и животных и исследование эволюции «в роде человеческом» [5, II, с.119]. Учёный опирается на концепцию казанского физиолога Н.О. Ковалевского, учитывает данные по теории эволюции видов и антропологии Ч. Дарвина. В работе «Происхождение видов» автор процесс «очеловечивания обезьяны» связывал не только с прямохождением, трансформацией кисти и стопы, возделыванием орудий, пользованием огнём, но и появлением членораздельной речи [3, с. 43]. Языковое состояние Homo sapiens И.А. Бодуэн де Куртенэ называет разными терминологическими словосочетаниями: первобытное образование языка, первобытное образование слова человеческого, первобытный язык, первоначальный язык, начало слова человеческого, начало языка [5, I, c. 64, 140, 209]. Специализированные лексемы первобытный язык / первоначальный язык, используемые И.А. Бодуэном де Куртенэ к дописьменным языкам разного времени, не имеют чёткой дифференциации. Названные специализированные выражения соотносятся с разными понятиями: 1) задатки будущего языка у младенца, «начинающего лепетать», и первобытное образование слова человеческого; 2) скудные задатки языка, унаследованные от предков; 3) первобытное состояние языка вообще = первобытное состояние языка дикарей; 4) эпоха образования первобытных языков [5, I, с. 64].

К термину первобытный язык апеллировал и Н.В. Крушевский в связи с изучением восприятия мира первобытным человеком и эволюцией языка. В его трактовке термин первобытный язык выступает как синоним терминов-понятий первобытное мышление, первобытное миросозерцание [4, с.26].

Чрезвычайно глубоким является противопоставление на терминологическом уровне понятий звук животного / звук человеческого языка. Их принципиальное различие И.А. Бодуэн де Куртенэ связывает с определённой конкретностью и развитой в звуке человека способностью к мышлению. Он резюмирует: звуки животного, будучи неизменяемыми, всегда остаются звуковым жестом, неспособным к абстракции, тогда как звуки человеческого слова «представляют собой абстракции ... тяготеют к мышлению и рассуждению...» [5, I, с. 261 - 262].

Процесс «человечения языка» осуществляется, по мысли учёного, благодаря трём составляющим: фонации, аудиции и церебрации. Значение этих терминов объясняет 
сам автор: «... фонация состоит в говорении ... аудиция - это слушание и восприятие сказанного ... церебрация ... есть закрепление всего того, что относится к языку, сохранение и обработка всех языковых представлений в языковой сокровищнице души, есть языковое мышление» [5, I, с.263]. Языковая жизнь, заключает И.А. Куртенэ, присуща лишь образам памяти (представлениям), т.е. понимается как жизнь психологическая. Звуки животных, включая антропоидов, всегда одинаковы, в то время как «слова человеческого языка способны принимать всё новые значения» [5, I, с. 261]. Эта мысль И.А. Бодуэна де Куртенэ нашла плодотворное развитие в современной лингвистике. Членораздельность (артикулированность) произношения автор связывает с ослаблением в большинстве языков придыхания (аспирации), активизацией работы губ, которая приводит к усилению лабиализации, продвижением вперёд заднеязычных, что вызывает их осреднеязычнение (палатализацию, смягчение) [5, II, с.120-124].

Описывая работу ротовой полости у древнего человека, И.А. Бодуэн де Куртенэ употребляет термины, часть которых легла в основу понятийного аппарата современной фонетики: передняя /средняя/ задняя части языка, органы подвижные / органы страдательные (неподвижные), твёрдое нёбо, верхняя губа, русская глосса язычок к латинскому термину (uvula) [5, II, c.119-120]. Признание И.А. Бодуэном де Куртенэ языка психофизиологическим явлением и одновременно явлением, испытывающим действие коллективно-индивидуального фактора, позволило разграничить два понятия: первоначальное человечение языка и историческое человечение языка. Первое словосочетание соотносится с начальным этапом «человечения» языка и отражает прогресс человека как одного из звеньев природы. Вторым словосочетанием лингвист называет процесс эволюции «внешней, звуковой стороны языка»[5, I, с. 263].

С лингвистической точки зрения обращает на себя внимание постановка казанскими учёными вопроса о языке детей, языковой деятельности детей; детской речи / речи детей [1, с. 317], начале языка, зародыше языка [5, I, с.143, 188], составляющего предмет особого исследования, которое «можно было бы назвать языковой эмбриологией» [5, I, с.143]. В современном термине детская речь (язык детей) сохранена констатирующая часть бодуэновской формулировки: «Детская речь - особый этап онтогенетического развития речи» $[6$, с.131]; «Детская речь - речь детей дошкольного и младшего школьного возраста (до 8-9 лет)» $[9$, с.4] .

Одним из первых к проблеме онтогенеза детской речи в её норме и в аномалии в разные периоды развития ребёнка обратился А.И. Александров. Он показал, что языковые аномалии в детской речи «не есть нечто новое в физиологии и психике», а представляют собой гипертрофию или атрофию языковых элементов [1, с. 93] . Сам автор их употребляет единожды, заменяя синонимичными словосочетаниями определительного типа увеличение звучания / сокращение звучания. При дефектах речевого аппарата у детей происходит замена трудных звуков на более лёгкие или наблюдается их опущение, но у детей отклонения от нормы преходящи [1, с. 101]. А.И. Александров констатирует в детской речи наличие звукоподражаний, изобразительных слов (слова-символы), нерегулярных слов (окказионализмы), созданных по регулярным моделям. Эти факты исследователь связал с особенностями детской психики [1, с.113].

В.В. Радлов ввёл в научный оборот термин детское языковое творчество, которым называл «все языковые элементы в языке детей», которые не имеют параллелей в литературном языке [7, с. 27] .

В.В. Богородицкий, термин речь детей употребляет в качестве противоположного термину речь взрослых в связи с опытом социальной дифференциации языка. Он констатирует, что различия в реализации языковой системы в разных социальных группах «многочисленны ... относятся ли они к разряду фонетическому, морфологическому, семасиологическому и проч.» [2, с. 274] .

В связи с проблемой эволюции человеческого языка И.А. Бодуэн де Куртэне первым в лингвистике противопоставил спонтанные речевые процессы у детей и рефлексирующие речевые процессы. Термином спонтанные речевые процессы называются бессознательные изменения звуков, которые происходят с большой 
скоростью [5, I, с. 143]; [4, с. 38]. Номинацией рефлексирующие речевые процессы И.А. Бодуэн де Куртэне обозначает качественное изменение и внутреннюю перестройку первоначально спонтанной речи [5, I, с.143].

В настоящее время выше названные проблемы разрабатываются в рамках рефлексивной психолингвистики. Наиболее заметной работой, написанной по следам публикаций казанских учёных, представлявшей на рубеже XIX-XX вв. педагогическое направление в изучении детской речи, является исследование В.П. Вахтерова, наметившего пути исследования детской речи $[9$, с. 6]. Традиции казанских исследователей, заложивших основы изучения детской речи, сегодня успешно продолжаются учёными РГПУ им. Герцена под руководством С.Н. Цейтлин.

1. Александров А.И. Детская речь // Русский филологический вестник. Варшава, 1883. Т. Х. № 3. С. 86120.

2. Богородицкий В.А. Об изучении русской речи // Русский филологический вестник (РФВ). Варшава, 1881. Вып.II. T.VI. № 4. С. 274-282.

3. Варшавский А.С. В поисках предков: Происхождение человека: миф и действительность. М., 1982. C.223.

4. Крушевский Н.В. Избранные работы по языкознанию/Составитель Ф.М. Березин. М., 1998.

5. Куртенэ И.А. Избранные труды по общему языкознанию. - М.: Изд-во Академии наук СССР, 1963. Т. I, II.

6. Лингвистический энциклопедический словарь (ЛЭС). // Под ред В.Н.Ярцевой. М.: Советская энциклопедия, 1990.

7. Радлов В.В. Вступительные мысли к описанию морфологии тюркских языков//Записки императорской академии наук по историко-филологическому отделению. СПб., 1906. Т.7. № 7. С. 19.

8. Срезневский И.И. Русь Угорская. Отрывок из Опыта географии русского языка // Вестник Императорского русского географического общества. СПб., 1851. Ч. 4. Кн.1-2. Отд. 2.

9. Цейтлин С.Н. Очерки по словообразованию и формообразованию в детской речи. М., 2009.

\section{Боброва Е.А., Иванова А.В. Анималистические метафоры в экономических текстах современного английского языка}

Байкальский государственный университет (Россия, Иркутск)

doi: $10.18411 / \mathrm{j}-30-06-2017-36$

idsp: 000001:lj-30-06-2017-36

\section{Аннотация}

Данная статья обращается к проблеме исследования метафоризации и метафоры с точки зрения современного когнитивно-ориентированного подхода к исследованию языковых единиц. Метод концептуальных метафор Дж. Лакоффа и М. Джонсона лежит в основе данного анализа метафоризации и его особенностей. Он осуществляется на примере исследования анималистических метафор, которые играют особую роль в деловом дискурсе. В статье приводятся примеры анималистических метафор из современных деловых текстов английского языка, выявляются основные причины широкого использования метафор животного мира в статьях о бизнесе и деловой среде.

Ключевые слова: концептуальная метафора, концептуальная система, деловой дискурс, метафоризация, концепт, когнитивная лингвистика, прикладная лингвистика

Концептуальная метафора прочно укрепились в работах современных ученыхлингвистов как привлекательный объект исследований. Связь процесса метафоризации с познавательными процессами уже не требует доказательств. Современные исследования по метафоре обычно затрагивают особенности метафоризации в разных дискурсах, различные концептуальные составляющие метафор, пространственные основы метафоризации и другие аспекты.Познание окружающего мира с помощью знакомых сущностей, закрепленных в концептуальной системе и в языке, и составляют суть 
концептуальной метафоризации. Как отмечают исследователи-лингвисты Дж. Лакофф, М. Джонсон человек мыслит метафорично. Объясняя более сложные процессы через привычные и знакомые, люди неосознанно прибегают к метафорам[4 ]. В своих работах исследователи-лингвисты анализируют механизмы метафоризации, подчеркивая ее тесную связь с концептами из пространственной сферы, доступными для восприятия объектами физического мира [2 ].

В данной статье акцент делается преимущественно на метафорах животного мира в английском деловом дискурсе, анализируется наиболее распространенные и популярные концептуальные метафоры: их этимология и семантика, а также делаются выводы о значимости концептуальных метафор в деловом английском языке.

Э. Джендрих, анализируя сферу применения метафор в современном английском языке, отмечает, что роль метафоры глубоко изучена в теоретическом аспекте, нонедостаточно исследована в прикладной лингвистике. Автор делает подробный анализ особенностей метафор в деловом дискурсе, предлагает свою классификацию, выделяя смысловые группы различных метафорических выражений. Перечень наиболее распространенных концептуальных метафор, выделенный Э. Джендрих, даёт возможность определить наиболее популярные и семантически емкие метафоры животного мира (animalmetaphors)[3, 129].

Среди наиболее употребляемых отмечаются следующие метафоры:

bearmarket (медвежий рынок, рынок медведей)используется в финансовой сфере для обозначения фондового рынка, который имеет тенденцию к снижению курса, т.е. понижающую тенденцию ;bullmarket(бычий рынок, рынок быков) - также употребляемся в финансовом секторе, и означает рынок, на котором наблюдается тенденция к повышению курсов; cashcow(денежная корова, дойная корова)- данный термин пришел в бизнес-язык из менеджмента. Используемый в Бостонской матрице, он означает хорошо известный на рынке товар, который приносит стабильную и высокую прибыль. EconomicTigers (экономические тигры) - экономический термин, использующийся для обозначения стран, переживающих период неожиданного и быстрого роста. Они сравниваются с тиграми, потому что экономика стран развивается стремительно, совершая большие скачки словно тигр. fatcat (толстый кот) - понятие экономического сектора. Синонимы данного понятия - капиталист, богач, денежный мешок, важная птица. Толстый кот используется как символ богатства, особых привилегий, достатка.gazellecompany (компания-газель) - экономическая метафора, используемая для обозначения молодых и энергичных, словно газель, компаний, которые недавно вышли на рынок, но стремительно растут и развиваются, loanshark (акулий заем) - метафора используется в банковском секторе для определения ростовщиков, заемщиков, дающих кредиты и займы под большие, «грабительские» проценты, в разы превышающие сумму займа. Такие займы кусаются как акулы и могут быть смертельно опасны для заемщиков. sharkrepellent(отпугиватель акул) - экономическая метафора, имеющая значение мер, принимаемых в компании для защиты от компаний, которые хотят ее поглотить. Здесь крупные компании, желающие поглотить, присоединить, другую компанию сравниваются с акулами, а меры по защите компании с отравой, отпугивателем акул. Необходимо отметить, что использование метафор, содержащих в себе слово «акула» (shark), придает контексту оттенок опасности, что достаточно правдоподобно отражает многие бизнеспонятия. snailmail(улиточная почта) - данная метафора не имеет узкой специфики, но активно применяется в бизнес-лексике, означая обычную почту. Обычная почта, в противовес экспресс-почте, курьерской доставке и т.д., сравнивается с улиткой, акцентируя внимание на медлительности такой почты.swansong (лебединая песня) широко используемая метафора, применяемая также и в бизнес-английском языке.Употребляется она как синоним шедевра, вершины творчества или иного яркого, значимого для человека поступка, совершенного им в конце своей профессиональной карьеры [3].

Иногда метафоризация охватывает не только отдельные фразы, выражения, отражающие те или иные процессы и аспекты деловой деятельности, но и является 
основой целого текста. Метафоризация на уровне текста представляет интересный пример концептуальной метафоризации, когда многочисленные отдельные метафорические выражения образуют единство образа целой бизнес-сферы, как например в статье «Whenegoscollide» («Столкновение самомнений»), опубликованной в газете The European и приведенной в учебном пособии «New Insightinto Business»[1, 177]. Автор статьи рассматривает происходящие в деловом мире процессы поглощения компаний через многочисленные аналогии с животным миром.

Анализировать бизнес-процессы гораздо проще, если проводится связь с уже известными и понятными предметами. Так автор статьи сравнивает поведение $\begin{array}{lllll}\text { руководителей фирм } & \text { с } & \text { непримиримым поведением }\end{array}$ приматов «...theparallelsbetweenthebehaviourofcorporateexecutivesandthatofgreatapes...»)(«... параллели между поведением руководителей компаний и приматами...»). Действительно, часто руководители компаний действует не совсем разумно: они не хотят идти на открытый контакт с противоположной стороной, усложняя переговоры.

Другое сравнение двух противоборствующих руководителей фирм (как представителей компаний) «...these two great beasts of the jungle (the CEO sof the corporations)...» («...эти два гигантских диких зверя в джунглях (топ-менеджеры корпораций)...») приводится автором через сопоставление высшего управляющего звена двух разных компаний с гигантскими дикими животными, а бизнес-среда сопоставляется джунглям. Две противоборствующие стороны, две огромные корпорации, не желающие идти на уступки и обладающие большой экономической силой, сравнением с двумя гигантскими зверьми, воюющими за территорию или ресурсы, упрощают понимание состояния этих компаний. Бизнес-среда, как джунгли, находится под влиянием силы (экономической силы) крупных корпораций. Сравнение бизнес-среды с джунглями обусловлено схожестью этих понятий: «дикие», враждебные условия, превосходство силы, сильных лидеров и т.д.

Похожий смысловой оттенок несет и следующее высказывание в статье «... with a power-hungry alpha male at the to pofeach company...» («...с голодными до власти альфасамцами на вершине каждой компании...»), каждая компания в лице топ-менеджеров борется за власть на рынке, долю своей продукции и за влияние отсюда и целесообразное сравнение.

Таким образом, проведя анализ существующих в английском деловом языке концептуальных метафор животного мира и изучив лингвистическую практику на основе статьи из СМИ, можно сделать следующий вывод. Концептуальные метафоры, в частности метафоры животного мира, помогают отразить сложные многоплановые процессы, происходящие в деловой среде. Такие концептуальные признаки анималистических метафор, как агрессивность, стихийность, непримиримость, стремление к доминированию и лидерству, борьба за территории и ресурсы, беспощадность, отражают суть бизнес-процессов емко и точно, помогая наблюдателю или участнику деловой среды, правильно оценить ситуацию и принять верные решения. Таким образом, в подобном лингвистическом анализе актуализируется роль концептуальной метафоры как объекта прикладной лингвистики, выводы которой помогут в решении практических задач.

$$
* * *
$$

1. TullisG., Trappe T. Newinsightintobusiness.Учебноепособие. / G. Tullis, T. Trappe // - Longman, 2007. C.177.

2. Боброва Е.A. Пространственная основа метафоризации концепта LOVE на примере современной англоязычной песенной лирики[Текст] / Е.А. Боброва //Сборник статей Международной научнопрактической конференции“Интеллектуальный и научный потенциал XXI века”(г. Волгоград, 23.05.2017). -Уфа: МЦИИ ОМЕГА САЙНС, 2017.- с.25-27

3. Дженрих Э. Метафора в деловой коммуникации / Э. Дженрих // Труды Санкт-Петербургского института культуры. - 2016. - №214, С. 117 - 133.

4. Лакофф Дж., Джонсон М. Метафоры, которыми мы живем / Дж. Лакофф, М. Джонсон // Теория метафоры. - 1990. -С. $387-415$. 


\section{РАЗДЕЛ ХІІ. ФИЛОСОФИЯ}

\section{Чумаков В.A. \\ Развитие России и мирового сообщества}

(Россия, Дзержинск)

doi: $10.18411 / \mathrm{lj}-30-06-2017-37$

idsp: 000001:lj-30-06-2017-37

\section{Аннотация}

В статье представлено понятие социальной устойчивости общества и возможности его осуществления, а также предсказано неизбежное будущее человечества, существующее в некапиталистической зоне развития.

Ключевые слова: устойчивость, национальная идея, деградация капитализма, ноосферный социализм.

На трудности управления общественным развитием влияет множество учитываемых и непредвиденных вероятностных обстоятельств политического, социального и производственно -экономического характера. Следует добавить, что принятие решений имеет, в большинстве случаев, субъективный, не всегда разумно мотивированный характер, и в совокупности с вероятностными воздействиями, препятствуют положительным результатам управления, а также заблаговременному определению качества регулирования социальной системы, её, так сказать, «устойчивости» существования. Кардинальные отличия социальных объектов: городов, областей или целого государства от технических систем автоматического регулированиятребует введения особого понятия социальной устойчивости развития [2, с. 141-147]. Функционирование регулятивного механизма, в идеале, должно обеспечивать существование социума в пределах, необходимых субъекту управления - властным органам [4, с. 111-120].

Качество социальной устойчивости социального объекта определяется знаком изменения социально - экономических показателей. В них входят: производство продукции, инвестиционные показатели, материальный уровень населения, демографические показатели, экологическая обстановка, степень самообеспечения, самодостаточности социального объекта и т. п. параметры, а для страны ещё необходимость оборонных приготовлений. Неубывающее изменение этих показателей формально свидетельствует о социальной устойчивости общества [2, с. 143-147]. Происходящее в социуме снижение этих показателей, указывает на неблагополучие в управлении развитием общества, о переходе системы в состояние деградации и упадка.

Для сравнения рассмотрим социальную устойчивость Советского Союза и РФ, на примере интегрального показателя «качество жизни», состоящего из трёх обобщающих показателей: экономической, экологической и социальной составляющих. Следует признать, что это сравнение не в пользу РФ. В период «развитого» социализма происходило растущее изменение этих показателей, говорящее о социальной справедливости, равноправии и прогрессивной эволюции. Города имели планы своего развития, подкреплённые финансовым обеспечением, строились промышленные предприятия, жилые здания, гражданские объекты, человек был уверен в завтрашнем дне, ощущалось не наигранное народное единство, был сформирован образ советского человека, называемого за границей то ли презрительным, то ли ласковым словом - совок. Мне, например, не чувствовалось ничего обидного в этом слове. Всего этого люди лишились при наступлении возвратного или повторного капитализма.

Какие причины способствовали тому, что внешне социально устойчивый социализм СССР, в сравнительно краткий по историческим меркам период, сменился капитализмом, в самом худшем его, коррупционном варианте. 
Социализм, как первая фаза коммунизма, являлся, в отличие от рыночного, частнособственнического капитализма, искусственно - организованным социальным образованием, с общественной формой собственности на средства производства. Сложным, не без ошибок, а подчас и кровавым происходил процесс смены формы собственности с частной на общественную, государственную, но свершившись, общественная форма собственности явилась фактором социальной справедливости и равноправия. Социальную устойчивость такого теоретически обоснованного, можно сказать, выдуманного общественного образования, каким являлся СССР, должны были обеспечивать выполнение необходимых и достаточных условий критериясоциальной устойчивости (КСУ). Его существо определяется близостью, можно сказать совпадением, соответствием социально-экономических действий руководства страны коренным пожеланиям и потребностям трудящихся масс.

Основные необходимые условия устойчивости социалистического государства состоят в минимально обоснованном оборонном потенциале, способном не допустить агрессивных действий противника из-за неминуемого ответного удара и неуклонного партийного курса на сохранение верности идеям коммунизма. Достаточные условия заключаются в экономическом само обеспечении страны и постоянном росте материального благополучия советских граждан, убеждающем в правильности выбранного компартией пути. История Советского Союза показывает регулярное отступление партийной и советской власти от этих разумных условий. Отсутствие грамотного регулятивного механизма управления, основанного на анализе информации, поступающей от ПЭК, необоснованная жестокость власти, личностные эгоистические мотивы, подрывные действия западных спецслужб послужили причинами разрушения советской страны, первого в мире социалистического государства.

Партийные руководители, к сожалению, забыли диалектику, неизбежность перемен в поэтапном созидании социалистического общества. Опора на старые социально-экономические и идеологические догмы уже не могли обеспечить ни темпов роста, ни должного воспитания трудящихся масс. Научно-технический потенциал отставал от достижений западной цивилизации, при всё более отдалении интересов правящих верхов от насущных интересов трудящихся масс, приведя, в конечном счёте, к разрушению социалистической страны, вместе с этим, к сожалению, развенчивая идею о справедливом общественном устройстве - коммунизме.

Возвратный капитализм ничем положительным себя не проявил. В начале 90 гг. прошлого века он был обманным путём внедрён в РСФСР командой Б. Ельцина, при попустительстве слабовольного и недальновидного М. Горбачёва. Была совершена преступная «прихватизация» народного достояния. Основная масса населения была ограблена «чикагскими мальчиками»: гайдарами, чубайсами, кохами и другими антисоветчиками, окружёнными многочисленными заокеанскими вражескими советниками, задачей которых было не реформирование социализма, а его скорейшее уничтожение. Советские люди были отстранены от управления страной, да они, в тайне, обработанные буржуазной пропагандой, надеялись на лучшую жизнь в капитализме. Однако довольно скоро народный миф о благородном и щедром капиталисте обернулся развалом былого социально - экономического могущества СССР, обнищанием и грабительской эксплуатацией народных масс [3, с. 21-31].

Катастрофическое падение экономики, безработица, самоуправство частных собственников, коррупция, суверенная демократия, означающая независимость избранной власти от своих избирателей, удерживающая несменяемую буржуазную властную команду - всё это говорило об отсутствии социальной устойчивости России, о её деградации. Поэтому статистические данные, обычные в Советском Союзе показатели роста страны, оказались почти секретными в РФ, поскольку данные Росстата, в основном, публиковались в специальных изданиях. Состояние страны её руководители стали лицемерно называть кризисом, ссылаясь на общее состояние мировой экономики, не видя своей вины за допущенные промахи управления. Власти не пытались вкладывать деньги в её развитие, рассчитывая только на инвестиции из-за рубежа. При этом, однако, тратили 
миллиардные средства на покупку американских облигаций, на зимнюю Олимпиаду в Сочи, а теперь ещё и на чемпионат мира по футболу 2018 года, имея в наличии посредственных футболистов. Всё это указывает на низкое качество управления РФ её властными органами, выражающееся в отсутствии заботы о своём государстве и его народе.

У народа простые желания, по глубине и смыслу представляющие народную национальную идею. Жить обеспеченно, иметь достойную работу, уверенность в будущем, ну совсем как при социализме, только, конечно, без особой жестокости и насилия, главной беды советской власти, особенно проявившейся в начале её существования. Однако у буржуазной власти свои представления о цели существования российского государства. Получается, что национальная идея имеет два источника: один идёт от смысла существования власти, другой от желаний народа, и только то общество будет обладать устойчивостью, согласно КСУ, у которого эти идеи совпадают. Таков смысл критерия справедливого и устойчивого общественного развития.

Цель власти, пришедшего в Россию возвратного капитализма, заключался в извлечении максимальной прибыли. Согласно политической экономии она возникает из процесса эксплуатации трудящихся масс, что никоим образом не совпадает с их потребностями. Не понимание, а точнее сказать незнание о КСУ властями РФ, забвение ими народных чаяний свидетельствует о принципиальной неустойчивости российского государства [3, с. 21-31]. Антагонизм существующих условий жизни, определяемых позицией власти и насущных ожиданий трудового народа, не может обеспечить долговременную устойчивость РФ.

Противоречие буржуазной социально-экономической политики интересам трудящихся масс не является только прихотью властных органов, она определена Конституцией РФ 1993 года, в которой прописаны противоречащие друг другу, а иногда просто невыполняемые статьи. Укажем только на малую часть нестыковок и странностей российской Конституции. Статья 7 указывает что: «РФ - социальное государство, политика которого направлена на создание условий, обеспечивающих достойную жизнь и свободное развитие человека». Вроде правильные слова о достойном устройстве общества, создающим основу его устойчивого развития, однако, люди не ощущают её реального воздействия на свою жизнь. В 20 статье записано странное «право на жизнь», касающееся отмены смертной казни преступникам - рецидивистам. Возникает вопрос об их необходимости обществу, если они способны на повторное убийство.

В следующей 21 статье провозглашается ещё более высокая забота о человеке: «Достоинство личности охраняется государством». Однако статье об охране «личного достоинства» противоречит 37 статья, в которой написано «Труд свободен», т. е. государство не берёт на себя ответственность за трудоустройство людей, фактически допуская безработицу в стране, а в некоторых случаях и преступления. Как же сочетается достоинство личности со свободой труда, во многих случаях ведущая к отсутствию работы из-за отсутствия промышленных предприятий? Как существовать человеку без работы, без жизненного содержания, на что ему достоинство, если кушать хочется, а работы нет!

Интересно сочетание 13 и 14 статей Конституции, в первой утверждается отсутствие государственной идеологии, во второй говориться о светскости РФ, т. е. об отсутствии клерикальной составляющей в действиях государственных структур. На деле всё чаще наблюдается соединение религии православия и действий госорганов. Разве не об этом свидетельствует стояние наших первых лиц в храмах со свечками в руках по большим религиозным праздникам, показывая пример остальным людям? Или присутствие президента на освящении храма в Сретенском монастыре? Реально светскость в РФ проявляется в виде защиты церкви от «нравственных» покушений со стороны безответственных людей, наносящих мало-мальский вред её моральному состоянию. Если церковь открыто прославляет Бога, то может ли атеист так же открыто высказать его мифологичность, т. е. не существование? Не попадёт ли он после этого под следствие? Несколько приведённых примеров показывают, что наша Конституция 
нуждается в реформировании и установлении адекватности существующим требованиям цивилизованного общества.

Нельзя не остановиться на вопросе устойчивости развитых капиталистических государств. Появление идей марксизма об общественной форме собственности на средства производства, их реализация на территории российской империи, появление Советского Союза заставило капиталистов основных западных стран пойти на некоторое смягчение эксплуатации, пойти на материальные уступки низшему сословию, в виде пособий по безработице, позволяющей безбедное существование. Уровень оплаты квалифицированных рабочих существенно вырос. Многие собственники средств производства пошли на предоставление небольшой части акций своим работникам, для повышения их заинтересованности в работе, делая их совладельцами предприятия.

Небольшое уменьшение прибыли хозяев предприятий с лихвой компенсировались политическим спокойствием в обществе. Большую роль в отсутствии левых настроений играет разрушение социализма в СССР, на обломках которого вырос коррупционный, полукриминальный возвратный капитализм с разваленной экономикой и бедным населением. Буржуазная пропаганда не устаёт повторять о низком уровне жизни в России, словно говоря: и вы такое хотите? Народ не хочет. Так власть обеспечивает относительную социальную устойчивость в стране. Однако этот путь ведёт к нравственному обнищанию и деградации населения, которое неизбежно приведёт к нарушению спокойствия, и гуманитарной катастрофе.

История, в лице первых коммунистов, предоставила России шанс показать всему миру истинное направление развития к счастью и процветанию человечества. Соблюдение необходимых и достаточных условий критерия социальной устойчивости должно было обеспечить продолжительное существование советского социализма. Это могло вызвать неминуемый рост числа стран, вставших на путь строительства социализма, что, в пределе, окрасило бы весь Земной шар в красный цвет социальной справедливости. Однородная коммунистическая идеология отбросила бы все распри и разногласия, установив абсолютную планетарную устойчивость на долгие времена. Ошибки советских руководителей дорого обойдутся последующим поколениям.

К этому добавилась слабость РФ, связанная с развалом приватизированной экономики. Небывалый рост долларовых миллионеров и миллиардеров, означающий коррупционную составляющую их доходов; некая «суверенная демократия», обеспечившая постоянное пребывание во власти одних и тех же лиц, более соответствующая авторитарному правлению, чем свободному волеизъявлению граждан; забвение развития науки, что вызвало бегство творчески одарённых людей из страны; помещение крупных капиталов за границей и многое другое, характеризующее недостаточно устойчивое управление страной, создало в мировом сообществе негативное отношение к РФ.

Западные страны получили возможность проводить свою, подчас бесконтрольную империалистическую мировую политику, добавляя к ней такое воздействие на опускание России, как экономические санкции. Войска НАТО подошли непосредственно к границам РФ, угрожая её безопасности и существованию. Осуждающее отношение западных стран усилил факт легитимного возвращения Крыма в РФ, а также их непонимание событий на Украине, отделение её юго-восточных областей от основного социального объекта.

Разобщённость территориально и экономически связанных государств обязана существующим капиталистическим социально-экономическим отношениям. Их движущей силой является алчность капиталистов, которые, по словам К. Маркса, при большом проценте прибыли не пожалеют и мать родную, а что тут говорить о чужих странах с чуждым этносом. Упование на возможное понимание проблемы отдельными странами, за которыми могут пойти остальные также утопично. Что надо сделать, например, в РФ для повышения её уважения в мировом сообществе? Установить пропорциональное налогообложение, отказаться от суверенной демократии, отойти от авторитаризма, отсечь коррупцию, поднять материальный уровень жизни - заняться 
внутренними проблемами. Но на это существующие в России власти, как показала практика, пойти не могут.

Капитализму, несмотря на благостную, в общих чертах, картину взаимоотношения власти и основных масс населения свойственна недопустимая социальная обстановка моральной деградации. Не прекращающаяся погоня за максимальной прибылью, конкуренция; эксплуатация человека человеком не только своей страны, но и тех стран, куда проникают западные монополии; омертвление выпускаемых бытовых товаров, ведущих к пополнению мусорных свалок, экологические бедствия.

Не нужда человека в гармоничном развитии, а максимальная прибыль довлеет над капитализмом. Отсюда и его страшный девиз: «человек человеку - волк», свидетельствующий о его неизбежном конце. Согласно регулятивно - диалектическому пониманию истории капитализм встретит неизбежный социальный, экономический и экологический барьер, который человечество сможет преодолеть, только встав на путь ноосферно - социалистического общественного устройства [4, с. 107-120]. Основу выполнения критерия планетарной устойчивости составляет отказ развитых стран от капиталистических социально - экономических отношений.

Существование капитализма противоречиво сочетает бурное экономическое развитие, приводящее к неустранимой социальной неустойчивости. Капитализм как общественно-экономическая формация нужна истории только как промежуточный этап перехода от дикости, невежества и суеверия феодализма к цивилизованному и справедливому устройству общества, в котором могут быть достойно развиты способности каждого человека. В этот период происходит, по словам того же Маркса, переход от предыстории человечества к подлинной его исторической сущности. Научно реформированные социализм и будущий коммунизм, при решительном отказе от жестокого принуждения, представляют достойные примеры подобного общественного устройства.

Хочется верить, что этот переход в действительности произойдёт. Капитализм встретит непреодолимый экономический и социальный тупик в своём развитии, который человечество сможет преодолеть, только встав на путь ноосферно - социалистического общественного устройства. Оптимальное управление планетарной устойчивостью будет возможно при наличии общей заинтересованности в интернациональном, дружелюбном и безопасном сообществе большинства развитых государств, при их добровольном участии в мирном общественном развитии. По словам президента ноосферной общественной академии наук, д.ф.н. А. И. Субетто: «Путь экологического спасения человечества пролегает через строй Ноосферного Экологического Духовного Социализма, который обеспечивает становление научно-образовательного общества и единственную модель устойчивого развития - управляемую социоприродную эволюцию на базе общественного интеллекта» [1, с. 54].

В настоящее время имеющееся понимание сущности Ноосферного Экологического Духовного Социализма, его превосходства перед капитализмом, не привело, однако, к пониманию процесса обретения этого общественного состояния, т. е. к замене капитализма ноосферным социализмом. Регулятивно - диалектическое понимание социальных процессов позволяет наметить основной путь его становления. Существующее в обществе совокупноеобщественное сознание, состоящее из сознания имущих и неимущих классов, постоянно взаимодействуют по закону единства и борьбы противоположностей. Превалирующее общественное сознание некоторого класса определяет стационарное состояние общественного устройства, его социальноэкономические отношения, а значит и власть. При сдвиге совокупного общественного сознания в иную сторону происходит соответственный рост классовой борьбы, и при благоприятных нестационарных условиях, может, произойти смена общественного устройства, изменение общественно - экономической формации [4, с. 111-120].

Количественные и качественные изменения соотношения составляющих общественного сознания являются предтечей социальных изменений. Изменение соотношения происходит в стационарном состоянии на основании информации, 
получаемой общественным сознанием от окружающего общественного бытия. В основе стационарного общественного существования лежит регулятивный механизмуправления, выполняемый сознанием человека или общества на основании информации, поступающей от материального окружения, т. е. бытия. Эта информация анализируется разумным комплексом человека или совокупным общественным сознанием, результат которого служит управлением поведения человека или общества для необходимого изменения его бытия, например, для совершения социальной революции [4, с. 111-120]. Процессы регулятивного взаимоотношения сознания и бытия не выходят из материалистического понимания существования социума. Бытие - объект управления информирует сознание, сознание - субъект управления изменяет бытие.

Справедливость подобного понимания взаимоотношения бытия и сознания, изменения в социально - экономических отношениях доказано всем историческим развитием человечества и отражено в регулятивно - диалектической философии (РДФ) [4, c. 114]. Согласно РДФ для изменения общественного устройства необходимо накапливать в общественном сознании потенциал сопротивления эксплуататорскому классу, чтобы в некоторый момент времени составляющая общественного сознания эксплуатируемого класса превзошла составляющую эксплуататорского класса и появилась возможность, путём классовой борьбы, изменения социально - экономических отношений, основы общественно - экономической формации.

По мысли В.И. Ленина первоначальное свержение буржуазного строя и установление общественной формы собственности на средства производства происходит в самом слабом звене мирового капиталистического сообщества. Анализ его существующего состояния позволяет сделать вывод, что им будет Российская Федерация.

$$
\text { *** }
$$

1. Субетто А. И. Роды действительного разума /Под научной редакцией Л.А. Зеленова. - СПб.: Астерион, 2015. $-200 \mathrm{c}$.

2. Чумаков В. А. К вопросу об оптимальном развитии городов Российской Федерации //Устойчивое развитие города: проблемы и решения. Материалы научно-практической конференции 10 декабря 2005 г. - Н. Новгород: Изд-во ВВАГС, 2006. - 347 с.

3. Чумаков В. А. Россия - испытательный полигон социальных экспериментов //Новые идеи в философии. Выпуск 19: Актуальные проблемы научной философии. Материалы всероссийской научной конференции, Пермь, 15-16 апреля 2010 г. Издательство Пермского гос. университета, Пермь, 2010 - т. 2. $-114 \mathrm{c}$.

4. Чумаков В. А. Регулятивно - диалектический материализм, как основа философии развития /Новая парадигма науки об управлении в XXI веке и её практическое приложение к проблемам Севера: монография. Том 2. Под науч. ред. А.И. Субетто и С.В. Арапова. - С-Петербург: Астерион, 2016. - 152 c. 


\title{
РАЗДЕЛ ХІІІ. ПЕДАГОГИКА
}

\author{
Kalenov A.A. \\ To the issue of the empirical study of the level of formation of subjectivity of senior \\ schoolchildren
}

doi: $10.18411 / \mathrm{j}-30-06-2017-38$

idsp: 000001:lj-30-06-2017-38

\section{Annotation}

The article discloses the generalization of methodological tools for the capacity to act diagnostics among senior schoolchildren, in accordance with the author's understanding of the capacity to act. A brief description of the modification of the methodology for studying the structure of the capacity to act for use in the sample of teenagers and senior schoolchildren is given in this paper. The subject matter of the methodological support package for the capacity to act formation diagnostics among senior schoolchildren is described, as well as a short step-bystep algorithm for data processing and derivation the integral level indicator of the capacity to act formation based on the obtained numerical values of separate components.

Keywords: capacity to act, components of the capacity to act among senior schoolchildren, capacity to act diagnostics, methods of diagnostics of the capacity to act among senior schoolchildren.

In the contemporary world, in various spheres of life and activity, a personality as a possessor of unique features and ways of activity implementation comes to the fore. The concept of personality itself is undoubtedly widely represented in modern science, and any interpretations of its subject matter include the same variables and criteria of definition: social conditioning, involvement in social space (belonging to a particular society and efficient existence in it), activity, awareness, responsibility, etc. Personality, as a specific social product, has a uniform understanding in science and is expressed by the axiomatic phrase: "one is not born a personality, one becomes a personality". Developing in the context of a certain socio-cultural and historical space, a person is the bearer of certain, peculiar to him, views, moral norms and values, philosophy of life. However, together with the concept of personality, as it is understood and accepted by the majority, a category of the capacity to act appears in science, and the absence of a uniform understanding of it generates some terminological confusion. The capacity to act, in the most general definition, is a feature of the personality that arises at a certain stage of its development as an expression of the ability to be a subject. The capacity to act does not exist apart from the personality, and it is one of its key characteristics. As distinctive features of the subject, in turn, researchers identify different units of analysis and options for methodological support of empirical research of the capacity to act.

The category of the capacity to act is considered from the point of view of various approaches and concepts as a feature, a specific characteristic of the personality (E.N. Volkova, S.D. Deryabo, V.A. Petrovsky, I.A. Seregina, etc.) as a function of the personality for implementation an activity of certain nature (V.I. Slobodchikov, E.I. Isaev, S.Z. Goncharov, N.V. Popova, etc.), as the highest level of expression of the ability to regulate behavior (M.V. Ermolaeva, P.V. Kondratieva, S.Z. Goncharov, N.V. Popova, A.K. Osnitsky, V.A. Petrovsky, V.O. Tatenko, etc.), as a prerequisite for and the way of personality development (A.A. Bodalev), etc. Common to all interpretations, in one aspect or another, is understanding of the capacity to act as a characteristic inherent to a personality as a social product and realized exclusively in the social space during activity expression [2]. Having analyzed a number of the above-mentioned and other (A.A. Bodalev, S.Z. Goncharov, N.V. Popova, S.D. Deryabo, M.V. Ermolaeva, P.V. Kondratieva, A.K. Osnitsky, V.A. Petrovsky, V.I. Slobodchikov, E.I. Isaev, V.O. Tatenko, etc.) models and approaches to the definition of the capacity to act and its structure, it is worth noticing some common points: 
1) conscious activity relatively to one's self, the world around and activity is recognized as the central characteristic of the capacity to act;

2) accepting oneself as a subject, possessing certain characteristics (responsibility, relative autonomy, integrity, independence, etc.), as well as recognition the right of others to be subjects and to demonstrate subjective qualities;

3) experience of the value and uniqueness of oneself [2].

Understanding of the category of "capacity to act" as itself, can be considered as a feature of personality, as a function of it, and as a specific form of self-regulation and conscious activity. Having generalized the results of the theoretical analysis, we accepted the following definition for the capacity to act: capacity to act is a system-forming central feature of a personality, that arises at a certain stage of its development and expresses itself in a specifically human conscious and active attitude to the world around and to oneself. The structure of the capacity to act includes as follows: awareness of activity, ability to goal-setting, self-regulation of activity and behavior, reflexivity, responsibility, self-awareness as a subject and unique personality and recognition of the same in other people [2].

In accordance with the proposed technology of the capacity to act formation among senior schoolchildren, it is necessary to monitor the level of the capacity to act formation at the initial and final stages of work on the selected components of the capacity to act [3]. Difficulties of methodical support consist in missing of the uniform instrument for diagnostics of the personality's capacity to act, as for the present time, but it is possible to use a package of complementary methodologies, the results of which can give a holistic view of the formation of individual components and the capacity to act in general. Having analyzed properly the means of diagnostics, available in the scientific and methodological literature, we formed the following package of methodological support for the capacity to act formation diagnostics among senior schoolchildren (table 1).

\section{Table 1}

The contents of the package of methodological support for the capacity to act formation diagnostics among senior schoolchildren

\begin{tabular}{|c|c|c|}
\hline $\begin{array}{l}\text { Components of the capacity to } \\
\text { act }\end{array}$ & Studying indicators & Methodologies \\
\hline $\begin{array}{l}\text { Awareness of activity, } \\
\text { reflexivity, responsibility, self- } \\
\text { awareness as a subject and } \\
\text { unique personality and } \\
\text { recognition of the same in other } \\
\text { people }\end{array}$ & $\begin{array}{l}\text { Levels of activity, ability to self- } \\
\text { reflection, freedom of choice } \\
\text { and responsibility for it, } \\
\text { awareness of one's uniqueness, } \\
\text { understanding and acceptance of } \\
\text { others, readiness for self- } \\
\text { development }\end{array}$ & $\begin{array}{c}\text { Questionnaire for studying the } \\
\text { structure of the capacity to act } \\
\text { by E.N. Volkova, I.A. Seregina } \\
\text { (in our own modification for } \\
\text { teenagers and senior } \\
\text { schoolchildren) }\end{array}$ \\
\hline Persc & $\begin{array}{c}\text { Level and orientation } \\
\text { (internal/external) of personal } \\
\text { control }\end{array}$ & $\begin{array}{l}\text { Methodology "Personal control } \\
\text { level" by E.F. Bazhin, E.A. } \\
\text { Golynkina, L.M. Etkind. }\end{array}$ \\
\hline Conscious self-regulation & $\begin{array}{c}\text { Level of development of } \\
\text { conscious self-regulation of } \\
\text { activity and behavior }\end{array}$ & $\begin{array}{l}\text { Questionnaire "Style of self- } \\
\text { regulation of behavior" by V.I. } \\
\text { Morosanova }\end{array}$ \\
\hline $\begin{array}{l}\text { Attitude to oneself as to a } \\
\text { subject of activity, ability to } \\
\text { goal-setting }\end{array}$ & $\begin{array}{c}\text { Awareness of the goals, } \\
\text { satisfaction with self-realization, } \\
\text { the locus of control (I/life), life } \\
\text { conciseness }\end{array}$ & $\begin{array}{c}\text { Test "Life-purpose orientations" } \\
\text { by D.A. Leontiev }\end{array}$ \\
\hline
\end{tabular}

Table 1 shows that package of methodological support for the capacity to act formation diagnostics among senior schoolchildren, formed by us, includes preferably well-known, standardized and reliable methodologies (Methodology "Personal control level" by E.F. Bazhin, E.A. Golynkina, L.M. Etkind; Questionnaire "Style of self-regulation of behavior" by V.I. Morosanova; test "Life-purpose orientations" by D.A. Leontiev), to focus on which separately within the framework of this article is inexpedient. Most of the components of the capacity to act (awareness of activity, reflexivity, responsibility, self-awareness as a subject and unique personality and recognition of the same in other people) are diagnosed, according to the 
proposed package, using the questionnaire for studying the structure of the capacity to act, by E.N. Volkova and I.A. Seregina [1; 4] in our own modification. Let us further consider the content aspects of this methodology and the specifics of the modification we have made.

The questionnaire for studying the structure of the capacity to act, by E.N. Volkova and I.A. Seregina, is intended for adults (teachers) [1; 4]. Despite the fact that most of the questionnaire's statements are fairly neutral and suitable for senior schoolchildren by semantic meaning, some statements still needed to be adjusted. Below are the items of the questionnaire that we modified for use in the sample of senior schoolchildren (Table 2).

Table 2

Modification of the items of the questionnaire for studying the structure of the capacity to act by E.N. Volkova, I.A. Seregina for use in the sample of senior schoolchildren

\begin{tabular}{|c|c|c|}
\hline $\begin{array}{c}\text { Initial statements of the } \\
\text { questionnaire }\end{array}$ & Modified formulation & Substantiation of the formulation \\
\hline $\begin{array}{l}\text { 16. Are you an independent } \\
\text { person? }\end{array}$ & $\begin{array}{c}\text { 16. Are you able to make } \\
\text { decisions based on your own } \\
\text { preferences and internal } \\
\text { needs? }\end{array}$ & $\begin{array}{l}\text { Independence for a senior school } \\
\text { child is most often limited by the } \\
\text { material and moral dependence on } \\
\text { the parents' family, age } \\
\text { restrictions, etc. }\end{array}$ \\
\hline $\begin{array}{l}\text { 24. Do you have the talent of a } \\
\text { leader? }\end{array}$ & $\begin{array}{l}\text { 24. Can you manage any } \\
\text { activity in a group of age- } \\
\text { mates? }\end{array}$ & $\begin{array}{c}\text { In our opinion, for teenagers and } \\
\text { senior schoolchildren there are not } \\
\text { many life situations where the } \\
\text { talent of a leader can be } \\
\text { demonstrated. To make it easier to } \\
\text { answer the question, without } \\
\text { change of its semantic meaning, } \\
\text { we have narrowed the scope of } \\
\text { leadership to a group of age- } \\
\text { mates. }\end{array}$ \\
\hline $\begin{array}{l}\text { 28. Does your job meet your } \\
\text { internal requirements? }\end{array}$ & $\begin{array}{l}\text { 28. Does your occupation } \\
\text { meet your internal } \\
\text { requirements and needs? }\end{array}$ & \multirow{2}{*}{$\begin{array}{l}\text { The semantic units "job" and } \\
\text { "professional" do not correspond } \\
\text { to the considered age range, } \\
\text { because the absolute majority of } \\
\text { senior schoolchildren is not } \\
\text { involved in any professional } \\
\text { activity, job as paid work. }\end{array}$} \\
\hline $\begin{array}{l}\text { 55. Do you aim to improve your } \\
\text { professional level? }\end{array}$ & $\begin{array}{l}\text { 55. Do you aim to reach new } \\
\text { level, develop your skills in } \\
\text { your favorite activities? }\end{array}$ & \\
\hline $\begin{array}{c}\text { 61. Do you prefer improvising } \\
\text { in class? (Note: in pedagogical } \\
\text { activity) }\end{array}$ & $\begin{array}{l}\text { 61. Do you have a desire to } \\
\text { improvise in various life } \\
\text { situations and activities? }\end{array}$ & $\begin{array}{l}\text { The semantic meaning of the } \\
\text { statement is preserved, but the } \\
\text { range of possible improvisation } \\
\text { spheres is expanded, because } \\
\text { frequently a lesson is not a } \\
\text { suitable form of activity for a } \\
\text { senior school child, where } \\
\text { improvisation is supported and } \\
\text { welcomed. }\end{array}$ \\
\hline
\end{tabular}

Thus, we have made a formal modification of the separate statements of the questionnaire with respect to semantic units that do not match the age of senior schoolchildren, with the preservation of the general sense. At the same time, in all the statements of the questionnaire, pronouns were replaced as follows: formal "you" with informal "thee", formal "your" with informal "thy", etc. This was done for the purpose of less formalizing the diagnostic procedure, reducing emotional tension, because these pronouns are used most often when referring to senior schoolchildren. Preservation, during the modification, of all the statements of the questionnaire by E.N. Volkova, I.A. Seregina with their semantic meaning unchanged, allowed to preserve the original author's key to the methodology, as a result of which data processing also allows obtaining information about the level of formation of such components of the capacity to act as awareness of activity, reflexivity, responsibility, self-awareness as a subject and unique personality and recognition of the same in other people. Pilot application of our modification of the questionnaire by E.N. Volkova, I.A. Seregina in a small sample of senior schoolchildren (52 persons), followed by a discussion with them the content of separate statements, showed that 
tested schoolchildren have proper understanding of the meaning of the questions, as well as a sufficiently developed self-reflection and self-awareness to answer them.

The proposed package of methodological support for capacity to act formation diagnostics among senior schoolchildren allows us to determine the level indicators of separate components, but does not answer the question about the formation of the capacity to act as an integral phenomenon. Therefore, it is necessary to integrate indicators by separate components, which will allow us to derive a single indicator of the capacity to act of a senior school child. For this purpose, it is expedient to implement the following steps:

- converting the numerical data for each indicator of the capacity to act into a scale of 1 to 10 (sten scale) using the standardization method;

- summarizing the sten values of all indicators of the capacity to act, the values obtained after standardization, and derivation of their average arithmetic, which is an assessment of the level of the capacity to act formation by a scale of 1 to 10 .

It is also seems to be useful to supplement the obtained indicator of the capacity to act with the profile of the capacity to act of senior schoolchildren, which can be represented visually as a graph, a column or a petal histogram, the ratio of all components of the capacity to act (in the sten values, obtained after standardization), which clearly shows which of them are formed to a greater, and which to a lesser extent. Such presentation of the results, in our opinion, will give a complete view of the studied feature and allow more efficient implementation of the technology of the capacity to act formation.

Thus, the package of methodological support for the capacity to act formation diagnostics among senior schoolchildren includes means for obtaining empirical data in connection with separate structural components of the capacity to act (awareness of activity, ability to goalsetting, self-regulation of activity and behavior, reflexivity, responsibility, self-awareness as a subject and unique personality and recognition of the same in other people). The processing of diagnostic data involves the construction of a profile of the components of the capacity to act and the derivation of an integral level indicator of the formation of the capacity to act based on the standardization of initial numerical data in the sten scale.

$$
* * *
$$

1. Volkova, E.N. Capacity to act by a teacher: theory and practice: Author's thesis of Doctor of psychological sciences: 19.00.07 [Electronic resource] / E.N. Volkova. - Moscow: PI RAO, 1998. - 50 p. - URL: http://www.dslib.net/psixologia-vozrasta/subektnost-pedagoga.html.

2. Kalenov, A.A. Referring to the issue of understanding of the capacity to act and its structure in scientific research [Electronic resource] / A.A. Kalenov // Education and training. - 2017. - No.1. - P. 3-7. - URL: https://moluch.ru/th/4/archive/52/1930/.

3. Kalenov, A.A. Subject matter of technology for creating situations of success for the capacity to act formation among senior schoolchildren in terms of the education process at school [Electronic resource] / A.A. Kalenov // Humanitarian tractate. - 2017. - No. 7. - P. 10-13. - URL: http://gumtraktat.ru/wp-content/uploads/v7.pdf.

4. Seregina, I.A. Psychological structure of the capacity to act as a personal characteristic of the teacher: Author's thesis of Candidate of psychological sciences: 19.00.07 [Electronic resource] / I.A. Seregina. - Moscow: PI RAO, 1999. - 26 p. - URL: http://www.dslib.net/psixologia-vozrasta/psihologicheskaja-strukturasubektivnosti-kak-lichnostnogo-svojstva-pedagoga.html.

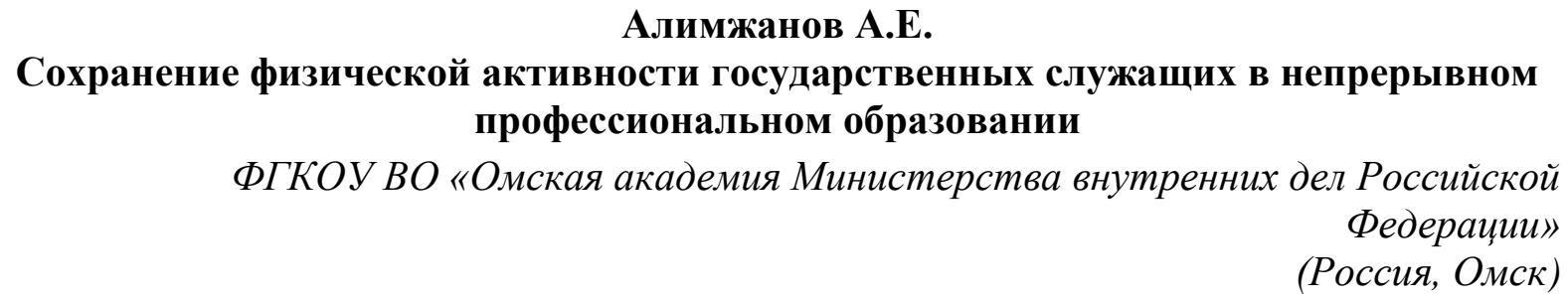

doi: 10.18411/lj-30-06-2017-39

idsp: 000001:lj-30-06-2017-39

\section{Аннотация}

В статье сохранение физической активности государственных служащих рассматривается как педагогическая задача, которая встраивается в процесс их 
самостоятельного непрерывного профессионального образования. Раскрыты организационно-педагогические условия успешности сохранения физической активности государственных служащих в процесс непрерывного профессионального образования.

Ключевые слова: физическая активность государственных служащих, сохранение физической активности, непрерывное профессиональное образование.

Эффективность профессиональной деятельности государственных служащих в значительной степени определяется уровнем их физической активности, которая целенаправленно и специально задается в основном в системе профессионального образования (физическая культура, физическая подготовка, соревновательная деятельность и пр.), а затем поддерживается и развивается государственными служащими самостоятельно. Проблема сохранения физической активности государственных служащих возникает в связи с тем, что далеко не все виды профессиональной деятельности государственной службы предполагают постоянное физическое напряжение, физическую нагрузку. Объективными факторами снижения физической активности являются: «кабинетная» работа и гиподинамия; служебная нагрузка и напряженный режим профессиональной деятельности, препятствующий регулярным занятиям спортом и физической культурой; повышение возраста и возрастные изменения здоровья, слабая медицинская активность; нарушение режима труда и отдыха; нездоровый образ жизни и вредные привычки и др.

Вместе с тем, снижение физической активности государственных служащих характеризуется и субъективными факторами, среди которых:

- несоответствие уровня знаний и представлений о роли физической активности в профессиональной деятельности актуальной ситуации профессионального развития специалиста (занимаемой должности, перспективам профессионального роста, характеру текущей и возможной профессиональной деятельности, возрасту, состоянию здоровья и пр.);

- отсутствие новых навыков, требуемых для сохранения физической активности на уровне, обеспечивающем нормальное самочувствие, работоспособность и эффективность выполнения профессиональных задач, пренебрежение занятиями физической культурой и спортом;

- восприятие физической культуры и спорта как внешнее требование, элемент контроля, а не как внутреннюю потребность человека, определяемую его активностью в целом.

Сочетание субъективных и объективных факторов делает сохранение физической активности государственных служащих педагогической задачей. В педагогическом смысле сохранение физической активности государственных служащих представляется нам как своевременное оснащение государственного служащего знаниями, умениями и опытом, актуализация соответствующей мотивации, а также развитие качеств, необходимых для сознательного, обоснованного, мотивированного выбора и удержания государственным служащим такого режима физической нагрузки, который обеспечивает его трудоспособность, поддержание здоровья и самочувствия, возможность выполнить потенциальные профессиональные задачи, характеризующиеся повышенным физическим и психическим напряжением. Выступая педагогической задачей, сохранение физической активности государственных служащих встраивается в процесс их самостоятельного непрерывного профессионального образования, связанного с самоизменением личности, сознательным «выходом» на новый уровень планирования и управления своей жизнью. По мнению О. Е. Шафрановой, оно возможно там, где ценностью для человека становится не только результат, но и сам процесс образования [1].

Непрерывное профессиональное образование несет в себе элемент организованности и системности в силу заинтересованности в его эффективности конкретных субъектов: работодателей, ведомств, а в случае с государственными служащими - государства и общества. Существует вполне определенный социальный заказ непрерывному профессиональному образованию, который в системе 
государственной службы РФ выражен ведомственными нормативными актами о подготовке кадров и квалификационными требованиями к должностям государственной службы (государственный заказ); общественным мнением и научными разработками (социальная часть); профессиональными нормами и традициями (корпоративная, социально-профессиональная часть); личными потребностями человека в здоровье, работоспособности и профессиональной самореализации (личностный заказ).

Проблема сохранения физической активности государственных служащих имеет эшелонированный характер, ее постановка зависит от вида государственной службы. Не выражена она в государственной военной службе (Вооруженные Силы и Национальная Гвардия РФ, другие аналогичные по профилю деятельности виды государственной службы), поскольку высокий уровень физического развития (и, соответственно, физической активности) является обязательным квалификационным требованием к военнослужащим, а физическая подготовка и спорт составляют обязательную часть военно-профессиональной деятельности. К этой же категории можно отнести оперативные структуры иных видов государственной (не военной) службы. Физическая активность здесь рассматривается в связи с установленными профессиональными требованиями к сотрудникам, а выполнение ими профессиональных задач требует развитых физических качеств, которые формируются и поддерживаются в рамках специальных занятий по физической подготовке. Однако в ряде работ даже на этом уровне уже прослеживается актуальная проблема мотивации и самостоятельности сотрудников, которая возникает при изменении условий их профессиональной деятельности [2].

Иной уровень актуализации проблемы сохранения физической активности характерен для сотрудников иных видов государственной службы, не занимающихся оперативной работой, но попадающих под требования руководящих документов к физической подготовке. Так, например, Е. В. Князева, классифицируя профессиональные задачи сотрудников правоохранительных органов по запросам к физической подготовке, выделяет группу сотрудников, деятельность которых носит «...камеральный, административно-канцелярский (кадровая и воспитательная работа, паспортно-визовая служба, лицензионно-разрешительная работа и др.) характер» [3]. Аналогичные виды профессиональной деятельности, не связанные с постоянными физическими нагрузками, существуют в таких видах государственной службы, как прокуратура, служба исполнения наказаний, таможенная служба и пр.

Наиболее проблемный уровень актуализации проблемы проявляется в отношении сотрудников государственной гражданской службы, где физическая активность практически не установлена в профессиональных требованиях и целиком отнесена к личной ответственности государственного служащего. Анализ современной научной литературы дает основания констатировать, что на этом самом критичном уровне проблема сохранения физической активности государственных служащих скрыта и практически не осмыслена.

Реализация педагогического пути вполне возможна в непрерывном профессиональном образовании государственного служащего при создании ряда организационно-педагогических условий:

1. Использование в организации непрерывного профессионального образования государственных служащих программно-целевого управления [4], которое предполагает постановку органами управления различных видов государственной службы самой цели сохранения физической активности государственных служащих, а также объединение усилий органов управления, образовательных организаций и образовательных подразделений для ее достижения за счет разработки и реализации педагогических программ в системе непрерывного профессионального образования.

2. Ресурсное обеспечение поддержки физической активности государственных служащих. Ее полное ресурсное обеспечение возможно при объединении административного, нормотворческого и информационного ресурсов органов управления видами государственной службы, научно-методического и образовательного ресурсов 
организаций образования или ведомственных образовательных подразделений, материально-технического и кадрового ресурсов системы физической культуры и спорта.

3. Глубокая индивидуализация и дифференциация педагогического взаимодействия с государственными служащими, сочетание организованных и самостоятельных занятий физической культурой и спортом.

Анализ основных концепций и теорий непрерывного профессионального образования в РФ свидетельствует о том, что в системе непрерывного профессионального образования возможна и обладает потенциальной эффективностью педагогическая поддержка физической активности государственных служащих. Это объясняется тем, что непрерывное профессиональное образование представляет собой организованное извне и управляемое пространство личностного развития субъекта профессионального труда, где через образовательные проекты возможно влияние на весь комплекс профессионально важных качеств личности, процессы самообразования и самостоятельного профессионального развития [5].

Непрерывное профессиональное образование государственных служащих имеет организованный, цикличный и частично управляемый характер [6], что позволяет ставить и решать долгосрочные задачи не только в образовательных проектах (в системе повышения квалификации, в профессионально-должностной подготовке), но и в довольно длительные периоды между ними (в самообразовании и самостоятельном профессиональном развитии, в дополнительном общем образовании и пр.). Организация непрерывного профессионального образования государственных служащих четко регламентирована федеральными законами о видах государственной службы, ведомственными нормативными актами, квалификационными требованиями к государственным служащим. Его ступенчатый, постоянно усложняющийся характер позволяет формировать уровневую педагогическую поддержку физической активности государственных служащих, содержание, формы и методы которой изменяются в соответствии с возрастом, состоянием здоровья и потребностями обучающихся.

Наконец, система непрерывного образования государственных служащих строится преимущественно кластерным методом, обеспечивающим особый способ взаимодействия организаций государственной службы и образовательных организаций. В сохранении физической активности служащих кластеры фактически составляют единое целое, преследуют общие интересы и получают права на использование совместных образовательных ресурсов. Такая связь делает принципиально возможной педагогическую поддержку физической активности государственных служащих в непрерывном профессиональном образовании.

Наиболее значимую роль в решении поставленной задачи играет активная часть непрерывного профессионального образования - система дополнительного профессионального образования, объединяющая различные формы целенаправленного и организованного педагогического взаимодействия с государственными служащими в процессе реализации дополнительных профессиональных программ (повышение квалификации, профессиональная переподготовка, стажировка и т. д.), обеспечивающих получение новых или повышение уровня имеющихся профессиональных компетенций, повышение профессиональной квалификации.

Таким образом, сохранение физической активности государственных служащих есть комплексная профессиональная проблема, для решения которой существуют и педагогические пути. При условии, что сохранение физической активности государственного служащего сочетает в себе личные, государственные и общественные потребности, признается всеми субъектами образовательной системы, дополнительное профессиональное образование может быть точкой приложения основных педагогических усилий в решении заявленной проблемы. Однако в вопросах сохранения физической активности государственных служащих, которое следует рассматривать как непрерывный процесс, большое значение приобретает межкурсовой период, где непрерывное профессиональное образование, несмотря на наличие активных форм 
педагогического взаимодействия (обучающие семинары, обмен опытом, занятия профессионально-должностной подготовки и пр.), имеет самостоятельный характер.

$$
\text { *** }
$$

1. Шафранова О. Е. Аксиология непрерывного образования преподавателя высшей школы: монография. Биробиджан: ГОУ ВПО «ДВГСГА», 2011.-271 с.

2. Шаповалов С. В. Методика физической подготовки оперативных сотрудников Федеральной службы Российской Федерации по контролю за оборотом наркотиков: дис. ...канд. пед. наук. - Хабаровск, 2012. $-224 \mathrm{c}$.

3. Князева Е. В. Физическая подготовка сотрудников ОВД, выполняющих работу камерального профиля: дис. ...канд. пед. наук. - СПб., 2003. - 138 с.

4. Близневский А. Ю. Программно-целевое управление развитием сферы физической культуры и спорта в пространстве Красноярского края: дис. ...д-ра пед. наук. - СПб., 2015. - 381 с.

5. Александров А. А. Вопросы теории и реализации непрерывного образования: монография. - М.: Изд-во МГОУ, 2012. $-270 \mathrm{c}$.

6. Ерегина А. Г. Дополнительное профессиональное образование как фактор профессионального развития государственных гражданских служащих: автореф. дис. ...канд. социол. наук. - М., 2015. - 28 с.

\section{Бехтер А.Ю., Волкова К.Ю., Евсеева Е.А. \\ Изучение иностранного языка (английского) при подготовке студентов к инженерной деятельности в неязыковом ВУЗе}

Пензенский государственный университет

(Россия, Пенза)

doi: 10.18411/j-30-06-2017-40

idsp: 000001:lj-30-06-2017-40

\section{Аннотация}

Основным содержанием деятельности инженера является разработка новых и оптимизация существующих инженерных решений.Обучаясь в ВУЗе,студенты получают какобщие, так и обще-профессиональные, инженерные знания. Изучение иностранного языка (английского), например,в значительной степени помогает в выбранной специальности.

Ключевые слова: инженер, деятельность, вуз, иностранный язык (английский), студенты.

Говоря об инженерной деятельности, прежде всего, следует отметить, что инженер - это специалист, осуществляющий инженерную деятельность. Как известно, инженеры вовлечены во все процессы жизненного цикла технических устройств, включая исследования, планирование, проектирование, конструирование, разработку технологии изготовления, подготовкутехнической документации, производство, испытание, эксплуатацию, техническое обслуживание, ремонт и утилизацию устройства, а также управление качеством. Основным содержанием деятельности инженера является разработка новых и оптимизация уже существующих инженерных решений. В своей деятельности инженер опирается на фундаментальные и прикладные науки. Основное отличие людей, выбравших профессию инженера, - это наличие аналитического мышления, хорошие теоретические и специальные прикладные знания, ориентированные на применение их на практике.

Как правило, работа инженера складывается из различных задач, для решения которых требуется аналитический склад ума, умение мыслить абстрактно. На сегодняшний день инженер - это человек, имеющий высокий уровень образования и подготовки, который готов выполнить любою организационную или даже творческую работу для решения поставленной задачи.

В последние десятилетия ряд технических отраслей испытывают характер бурного развития: информатика и системы обмена информацией, компьютеры и компьютерные системы диагностики и управления, лазеры и лазерные системы связи, наведения, противодействия. Основой становления перечисленных направлений явилась классическая и квантовая электроника, радиотехника. 
Получить профессию инженера можно практически в любом техническом ВУЗе России, на базе которого функционирует инженерный факультет.

Современных студентов в специальности «Радиоэлектронные системы и комплексы» (РЭСиК) привлекает: постоянная востребованность профессии, возможность постоянного развития в профессиональном плане, высокий уровень оплаты труда, возможность реализовать свои изобретательские навыки,постоянная востребованность профессии в современном мире и в обозримом будущем. Мир электронной техники динамично обновляется и поэтому инженеру-электронщику необходимо постоянно находиться в курсе всех новшеств и изобретений, а также овладевать навыками работы с этими изобретениями.

Таким образом, выбранная нами инженерная специальность «Радиоэлектронные системы и комплексы» не случайна, поскольку в последнее время современное общество нуждается в квалифицированных специалистах этой сферы деятельности.

Радиоэлектронные системы и комплексы (РЭСиК) являются вершиной самых последних научных и технических достижений радиотехники, электроники, лазерной техники. Данная специальность включает в себя многофункциональные ансамбли техники, решающие задачи связи, обмена информацией, локации, навигации, радиоэлектронной борьбы.

Специалист по радиоэлектронным системам и комплексам в самой радиоэлектронике и в смежных областях знает все. Ему понятны принципы действия и устройство всего, что относится к радиотехнической, электронной, лазерной аппаратуре бытового, промышленного, космического и военного назначение. Поэтому, если студент овладеет знаниями в объеме читаемых по РЭСиК дисциплин, то он гарантирует себе занятость, востребованность и хороший заработок, независимо от экономических, политических, социальных катаклизмов и потрясений. Кроме того, данная специальность готовит высокооплачиваемых и востребованных у работодателей квалифицированных специалистов высокого уровня, так как бакалавр - это базовое образование, а специалист - полное.

Наша специальность является системотехнической. Специальности данной сферы учат мыслить, решать проблему глобально, в комплексе, учат проектировать не отдельные устройства, а целые системы.

Ну а что, если учеба позади, диплом в руках. Куда же пойти работать?

Во-первых, в крупных городах существует ряд государственных предприятий. Как правило, эти предприятия заключают договоры с факультетами на целевую подготовку специалистов. То есть подписывается договор между предприятием, ВУЗом (факультетом) и студентом, по которому ВУЗ обучает студента, за это обучение платит предприятие, а студент, после окончания учебы, обязывается отработать определенное количество лет на данном предприятии. Также существует другой вариант - студент (как правило, учащийся на последнем курсе) начинает работать на этом предприятии.

Во-вторых, в сферу изучения студентов радиофакультетов входят технологии беспроводных систем передачи данных - их практика и теория. Это технологии Bluetooth, Wi-Fi и WiMAX. Этим технологиям учебники и бесчисленное множество статей и ресурсов в Интернете. То есть, выпускник радиофакультета может быть не просто системным администратором, но и специалистом по беспроводным сетям, а востребованность таких специалистов более чем высока.

Обучаясь в ВУЗе мы получаем общие знания (такие как история, философия, иностранный язык и другие) и обще-профессиональные, инженерные знания. Изучая иностранный язык (английский), например,студенты изучают слова, термины, значения, относящиеся к указанной сфере деятельности.

Знание иностранного языка в значительной степени помогает в выбранной специальности. Так, например, чтобы работать инженером связи необходимо знать правила эксплуатации средств связи (которые часто бывают на иностранном языке). То есть необходимо представлять, каким образом происходит обмен информацией между устройствами, как проводится их техническое обслуживание, как работает оборудование и в каком режиме. Существуют специально разработанные правила и нормы выполнения работ по техническому обслуживанию. Инженеры связи руководствуются ими, когда составляют заявки на оборудование, расходные материалы или на запасные части. Они работают в телефонных компаниях, корпорациях сотовой связи, телекоммуникационных 
фирмах, организациях, предоставляющих пользователям интернет-услуги и сотовую связь. А для этого владение иностранным языком тоже необходимо.

Сфера работы инженера-связиста с каждым днем расширяется, так как появляются новые технологии, более усовершенствованные виды связи и компьютерного обеспечения. Именно поэтому, будущему специалисту необходимо изучение технического английского языка.

Знания иностранного языка помогут расширить спектр возможностей будущего специалиста. Ведь, на занятиях студентов учат, как правильно писать деловые, личные иофициальное письма, причём, электронный вариант, отправляемый по почте существенно отличается от бумажного. Как строить диалог, грамотно отвечать на вопросы, переводить различные тексты, как художественного, так и научного характера. Кроме того, студенты готовят презентации и небольшие проекты о научных инновациях, которые появляются непосредственно, в инженерной сфере деятельности. Проделывая всё это под руководством преподавателя, студенты получают незаменимый практический опыт.

Обладая данными навыками, можно будет претендовать на более высокую заработную плату, вести переговоры с иностранными компаниями, или даже работать заграницей. Пензенский Государственный Университет, а именно наша кафедра «Радиотехника и радиоэлектронные системы» сотрудничает с такими крупными предприятиями, на территории Пензенской области, как ФГУП ФНПЦ "ПО "Старт" им. М.В. Проценко", НИКИРЭТ - филиал ФГУП ПО «Старт», Пензенское отделение ОАО МСС-Поволжье «Мегафон», Пензенское отделение ОАО МСС-Поволжье «Мегафон» и др. С 2004 г. по настоящее время действуетМеморандум соглашения о научном сотрудничествемежду кафедрой "Радиотехника и радиоэлектронные системы" Пензенского государственного университета и кафедрой электротехники и вычислительной техники Школы инженерных и прикладных наук Университета Джорджа Вашингтона, США. (Memorandum of Understanding for Scientific Cooperation between the Department of Electrical and Computer Engineering of the School of Engineering and Applied Sciences of the George Washington University and the Department of Radio Engineering of the Penza State University, Russia).ВУЗ даёт студентам хорошую «почву» для развития науки совместно с иностранным языком.

Подводя итог всего выше сказанного, можно сделать вывод о том, что английский язык, как предмет необходим будущему специалисту для достижения высоких целей и для расширения собственного спектра возможностей.

Галушко И.Г.,Галушко А.В.,Маркувинас И.В. Педагогическое общение как фактор эмоционального благополучия ребенка

Кубанский государственньй университет (Россия, Краснодар)

doi: $10.18411 / \mathrm{l}-30-06-2017-41$

idsp: 000001:lj-30-06-2017-41

\section{Аннотация}

Данный статья посвящена влиянию педагогического общения на эмоциональное благополучие детей. Сфера общения - самый мощный источник, который определяет психическое развитие и становление человека как личности. Благодаря наблюдениям можно прийти к выводам о том, что выбор жизненного пути ребенка во многом зависит от позиций педагога и методов его преподавания. Тип общения взрослого с ребенком, главным образом влияет на детское развитие.

Ключевые слова: общение, развитие, влияние, педагог, воспитание, формирование, обучение.

Педагогическое общение - некая связь педагога с учениками в учебновоспитательной деятельности. Она нацелена на формировании подходящего психологического климата, который положительно сказывается на эмоциональном 
состоянии ребенка, а также его интеллектуальном развитии. Основные правила педагогического общения:

- Проявлять педагогический такт.

- Уметь: устанавливать связь с детьми; проникаться их состоянием и поддерживать при любых обстоятельствах; сохранять положительный эмоциональный тон, сопровождающийся мимикой пантомимикой; жестикуляцией и разговорной речью привлекать к себе собеседника(общедоступность, выразительность, последовательность, краткость); слушать с интересом и почтением; никак не останавливать собеседника; обладать ораторскими данными (тон, дикция, произношение);

- Уметь: распоряжаться собственными эмоциями (выталкивание негативных помыслов из головы); установка на позитивное восприятие собеседника; обладать способами поддержания эмоционального благосостояние детей, так как это сказывается на их работоспособности. Значимым фактором формирования психологического благосостояния считается необходимость создания благоприятного климата.

От персоны преподавателя и его мер воздействия на ребенка зависят конечные результаты воспитательного процесса. В ходе общения с чадом старшие обязаны не просто на теоретическом уровне делиться с ребятами собственным опытом и знаниями, а являться настоящим эталоном для подражания.

Настоящее педагогическое общение подразумевает субъектные взаимоотношения: партнеры в результате общения создают определенную связь, которая характеризуется наличием уважения и понимания у обеих сторон по отношению друг к другу. Если в общении преподавателя с ребенком отсутствует взаимная направленность т. е. дети здесь являются лишь объектом воздействия, то в таком случае невозможно сказать о полноценном общении. От поведения педагога зависит его дальнейшее взаимодействие с воспитанниками, которое оказывает большое влияние на развитие самосознания детей, на их взаимоотношения и коммуникабельность.

Главной задачей общения выступает стремление преподавателя гарантировать ребятам ощущение эмоциональной безопасности, доверия к обществу. Истинный педагог не должен оценивать развитие детей по конкретным образцам и критериям. Он учитывает личностные особенности каждого ребенка, стремится создать благоприятные условия для всестороннего развития. Ребенку предоставляется определенная самостоятельность, его активность не подавляется.Не спроста опытнейшие педагоги как можно больше времени проводят с детьми. Они, подготавливаясь к уроку, воспитательному мероприятию, празднику подробно продумывают каждую организаторскую деталь: не просто план проведения мероприятия, а то - с кем кого посадить, например, чтобы каждый чувствовал себя комфортно. Общение на досуге, на занятии, во внеклассной работе является важным условием развития учебно-воспитательного процесса, а также стимулом для дальнейшего развития.

Именно поэтому в общении педагога с детьми необходимо использовать крайнюю осторожность в подборе ни только манеры общения, но и формы обращения. Такой вид общения должен отличаться некой легкостью и непринужденностью. Особое внимание необходимо уделять деткам дошкольного возраста, так как именно они нуждаются в обучении, которое направлено на постановку правильной речи и общения.

Педагог является для детей неким спутником, который всегда укажет верну дорогу и отведет от бед. Кроме того, педагогу необходимо постоянно учиться, развиваться и познавать этот мир во всех его проявлениях. Ведь чему может научить человек, который сам не придерживается определенных правил и установок? Так, что роль педагога требует полной самоотдачи, непрерывного саморазвития, открытости и такта. При наличии этих качеств, педагог становится для детей настоящим маяком, ориентиром в этом мире, о котором они вспоминают с теплые долгие годы.

$$
* * *
$$

1. Лобанова, Е.А. Дошкольная педагогика: учебно-методическое пособие. Николаев, 2005.

2. Сластенин, В.А. и др. Педагогика: Учеб. пособие для студ. высш. пед. учеб. заведений. М.: Академия,

3. Столяренко, Л.Д. Педагогическое общение. Ростов: Феникс, 2004.

4. Толочек, В.А. Стили профессиональной деятельности. М.: Смысл, 2000. 


\title{
Галушко И.Г., Галушко А.В., Дураченко А.Д. Характеристика и средства педагогического общения
}

\author{
Кубанский государственньй университет
}

(Россия, Краснодар)

doi: $10.18411 / \mathrm{lj}-30-06-2017-42$

idsp: 000001:lj-30-06-2017-42

\section{Аннотация}

Педагогическое общение считают одной из главных проблем современной педагогики и педагогической психологии. Интерес к этой проблеме был вызван в связи с изменениями внутри самой педагогической системы, а также с поиском путей для повышения продуктивности деятельности педагога.

Ключевые слова: педагогическое общение, педагогическое взаимодействие, функции общения, навыки, средства.

Общение присутствует во всех видах человеческой деятельности. Но есть определенные формы труда, где оно выступает не как конфигурация обыденного взаимодействия людей, а как функциональная категория. Как раз активным и мастерски весомым считается общение в педагогической работе. Оно выступает как инструмент влияния, и обыденные обстоятельства функции общения получают ту вспомогательную «нагрузку», так как переходят из общечеловеческих качеств в составляющие функционально - творческие.

Главная задача педагогического общения способность передавать социальные и профессиональные навыки от преподавателя к ученикам, например и в обмене личными смыслами, связанными с изучаемыми объектами и жизнью в целом.

Преподаватель считается основателем данного процесса, организуя его и управляя им. Он каждый день воплощает в жизнь многогранную коммуникативную работу, выступая и как ключ информации, и как человек, познающий учащегося или же группу людей. Самой общепринятой оплошностью молодых учителей - неумение осуществить педагогическое общение целостно.

Помимо информационной функции педагогического общения, возможно отметить и ряд иных его функции:

- контактную - установление связей как состояния взаимной готовности к способу и обмену информационным сообщением и поддержания связи в форме неизменной взаимоориентированности;

- побудительную - стимулирование энергичности студента, направляющую его на выполнение необходимых учебных действий;

- амотивную - помощь развития в ученике подходящих психологических эмоций, а еще перемена с его поддержкой личных переживаний и состояний и др.

Педагогическое общение не должно ориентироваться лишь только на амбициях человека как самое важное значение общения. Огромное смысловое значение для продуктивного общения имеют такие этические значения, как добросовестность, откровенность, бескорыстие, доверие, милосердие, признательность, внимание, преданность тексту.

Суть педагогической работы заключается в том, дабы показывать учащимся собственную эрудицию в тех или же других областях познаний и в конкретной мере содействовать модификации им части данных познаний. При этом общении люди конкретным образом оказывают воздействие на психическое или же телесное здоровье напарника. Лишь благодаря, кондиционному общению наставник имеет возможность унять огорченного бедой учащегося, тренер - поднять дух спортсмена перед стартом, а некто станет беспокоиться о том, дабы расстроить настроение собственному противнику в раздоре. 
Одной из необходимых черт общения считаются способы общения, которые возможно выделить как методы передачи информации и выражения отношений между партнерами в процессе их взаимоотношений. В зависимости от средств общение имеет возможность быть конкретным и опосредованным, прямым и косвенным, вербальным и невербальным.

Конкретное общение исполняется с поддержкой натуральных органов, данных человеку природой: рук, головы, тела, голосовых связок и т.п.

Опосредованное общение связано с использованием особых средств и орудий для организации общения и обмена информацией между людьми.Примером опосредованного общения имеет возможность быть проверка учителем письменной работы учащегося.

Косвенное общение исполняется сквозь посредника. Партнеры непосредственно не лицезреют и не слышат друг друга, а передают информацию через третью личность, выступающего в роли посредника.

Ключевым средством профессионально-педагогического общения считается язык, людская речь. Специалисты по психологии именуют это общение вербальным, т.е. словесным, потому что информация меж контактирующими передается с поддержкой текстов.

Таким образом, следует отметить, что собственно педагогическое общение существует ровно столько, сколько существует сама школа и образовательный процесс. Ведь как только начинают взаимодействовать педагог и ученик, то сразу и возникает процесс педагогического общения и его трудности. Регуляция навыков педагогического общения очень важна для развития детей, это определяет уровень его способностей, возможность мыслить и находить пути решения из трудных ситуаций.

$$
* * *
$$

1. Пиз А., Гарнер А. Язык разговора / Пер. с англ. Т.Новикова. - М.: Эксмо, 2007. - 223 с.

2. Болотова, А.К. Социальные коммуникации. Психология общения: Учебник и практикум для академического бакалавриата / А.К. Болотова, Ю.М. Жуков, Л.А. Петровская. - Люберцы: Юрайт, 2016. $-327 \mathrm{c}$.

3. Ильин, Е.П. Психология общения и межличностных отношений / Е.П. Ильин. - СПб.: Питер, 2013. - 576 c.

\section{Галушко И. Г., Лопатюк Е.А., Кустова Д.М. Барьеры в педагогическом общении}

Кубанский государственньй университет (Россия, Краснодар)

doi: $10.18411 / \mathrm{j}-30-06-2017-43$

idsp: 000001:lj-30-06-2017-43

\section{Аннотация}

В общении формируется существенная концепция воспитательных отношений, содействующих производительности обучения и преподавания. В преподавательской деятельности общение обретает многофункциональный и весомый характер. Оно представляет собой механизм влияния, и простые требование и функции общения приобретают тут вспомогательную «нагрузку», таким образом, аспекты общечеловеческих нюансов переходят в элементы педагогической оригинальности.

Ключевые слова: общение, воспитание, педагогика, барьеры, фактор, взаимодействие, страх.

Исследования трудностей общения и практические исследования дают возможность использовать многочисленные приемы для межличностных отношений. В основном главными критериями межличностного общения считаются умения и навыки каждого для применения их в так называемых директивных приёмов реагирования при общении.Главными факторами неэффективности каждого настоящего общения является 
применение оборонительно-враждебной конфигурации или иными словами агрессивные действия.

В жизни человека, как в личной так и профессиональной имеются цели, которые должны включать в себя:

- достижения полного взаимопонимания с партнером;

- психическое воздействие на партнёра для отстаивания своих интересов;

- собственной защите от нападок и агрессии;

Защитно-враждебное общение - это взаимодействие, направленное на психическое воздействие на собеседника в личных интересах, но проявляется в такой форме, чтобы унизить чувство собственного достоинства собеседника.

Установка в слаженности собственного поведения при общении с людьми значит проявление своей искренности в общении с ними. В практике слаженность действия обладает большой ролью в таком случае, когда мы проявляем на деле действительно те чувства, которые переживаем внутри в момент общения и тогда, когда мы сами осознаем своё эмоциональное состояние.Быть целиком слаженным в общении с абсолютно всеми людьми, все время и абсолютно во всех моментах разумеется невозможно, но слаженность поведения очень важна в тех ситуациях, когда собеседники хотят понять друг друга и хотят развивать свои взаимоотношения.

Одним из факторов появления психологического барьера могут быть социокультурные отличия между собеседниками в процессе общения. Различная интерпретация понятий, употребляемых в общении, может зависеть от сферы деятельности: политика, религия, общество. Так же в роли барьера может выступать само понимание партнёра в общении, как личности определенной деятельности, национальности, пола и возраста.

Психологические барьеры в общении появляются малозаметно и индивидуально, зачастую они никак не чувствуются лично самим человеком, однако немедленно замечаются со стороны окружающих. Человек перестает чувствовать неточность собственных действий, и убежден, то что контактирует естественно.

Первое впечатление является одним из барьеров, который способен содействовать ошибочному восприятию собеседника. Первое впечатление, согласно сущности, не всегда бывает первым, так как на восприятие образа влияет как зрительная, так и слуховая память.

Барьер предвзятой установки выражается в следующем: человек беспричинно начинает отрицательно относиться к собеседнику либо по результату первого впечатления, либо по скрытым личным причинам.

Барьер негативной установки: нам сообщают отрицательную информацию о комлибо, в процессе чего устанавливается негативная установка по отношению к человеку,с которым мы раннее не взаимодействовали лично.

Барьер "страха" в общении с человеком: возникают такие моменты, когда нам необходимо вступить в контакт с определенным человеком, но мы боимся это сделать. Так как же вести себя в таких ситуациях? Для начала необходимо спокойно, без лишних эмоций проанализировать, какие факторы нас сдерживают и убедиться в том, что это всё субъективно и имеет второстепенный характер.

Барьер возраста. Люди более старшего поколения зачастую осуждают поведение молодых,a со стороны молодых в такие моменты исходит агрессия.Таким образом,возникают осложнения в отношениях разных поколений.Барьер возраста весьма опасен в различных сферах,как в семейных отношениях,так в социальной сфере(работа).

Схема выхода из ситуации "барьера":

1)оценка сложившейся ситуации барьера, её возможные последствия;

2)обнаружение причин возникновения барьера;

3)определение дальнейших действий для выхода из ситуации.

Для решения проблемы “барьеров” необходимо как можно точно оценить ситуацию, выяснить основные причины и действовать намеченному плану. При этом 
необходимо учесть основной принцип: принцип взаимопонимания с учетом индивидуальных и психологических особенностей собеседника.

1. Пастюк, О.В. Психология и педагогика: Учебное пособие / О.В. Пастюк. - М.: НИЦ ИНФРА-М, 2013. $160 \mathrm{c}$.

2. Пидкасистый, П.И. Психология и педагогика: Учебник для бакалавров / П.И. Пидкасистый. - М.: Юрайт-Издат, 2013. - 724 с.

\section{Галушко И. Г., Лопатюк Е.А., Новикова К В. Основные правила педагогического общения с детьми}

Кубанский государственньй университет (Россия, Краснодар)

doi: $10.18411 / \mathrm{j}-30-06-2017-44$

idsp: 000001:lj-30-06-2017-44

\section{Аннотация}

Жизнь каждого человека практически зависит от общения, которое заложено в основе деятельности людей. Психологический словарь толкует слово "общение" как "взаимодействие двух или более людей, состоящее в обмене между ними информацией познавательного или аффективно-оценочного характера". Гуманистическая психология отдает общению основное, базовое место среди потребностей человека. Лишь благодаря общению люди обмениваются эмоциями и информацией.

Ключевые слова: общение, педагогика, психология, взаимодействие,

Педагогическое общение - это «взаимодействие преподавателя с учащимися в учебно-воспитательном процессе, направленное на создание благоприятного психологического климата, способствующего более полному развитию личности». (Функциями педагогического общения являются познание, обмен информацией, организация деятельности, обмен ролями, сопереживание, самоутверждение).

Процедура общения заключается напрямую в самом акте коммуникации, в котором примут участие общающиеся. При этом обычно их обязано являться двое и более.

Главные основы общения с ребенком:

1. Абсолютное принятие ребенка - исходный положительный подход к детям, согласие со всеми их индивидуальными чертами, минусами, ошибками, бедами. Принятие означает проявление терпимости, стремление к пониманию его и помощи.

2. Проявлять уважение к человеку и поддерживать чувство достоинства в каждом.

3. Осознать и признать право личности к стремлению развития индивидуальности, непохожести.

4. Предоставлять право свободного выбора.

5. Оценивать не личность детей, а их деятельность.

6. Владеть способностями к восприятию и пониманию всех людей, уметь видеть проблемы глазами ребенка.

7. Вероятность принимать во внимание индивидуальные психологические характерные для ребенка черты.

Набор основных правил педагогического общения:

- умение к проявлению педагогического такта;

- умение к определению по внешним признакам состояния ребенка; поддерживание мимикой, поза высказывания партнера по общению;

- выслушивание с пониманием и уважением; не иметь привычки прерывать; овладение и развитие культуры речи (доступная, образная, логичная, лаконичная);

- управление при помощи голоса (интонации, дикции); 
- управление при помощи мимики, жестов; постараться снизить речь вида монолога в диалоге.

- способности к управлению собственными состояниями и чувствами; настрой на благоприятное восприятие собеседника; овладение приемами развития и применения эмоций тепла, любви, доброжелательности.

Инновационные ресурсы массовой коммуникации поспособствовали появлению новейших течений изучения форм общения различных типов, таких как телефон, телевидение, радио, Интернет и другие. Таким образом, взаимная деятельность опосредована общением.

Только при помощи общения люди вступают во взаимодействия. По-другому, взаимодействие можно назвать интеракцией, по определению это коллективная работа, рассматриваемая со стороны социальной организации. Затрагивая общение, можно сказать, что оно является фактором интеракции. Если эти факторы используют в ситуации взаимодействий, то они будут относиться к коммуникативным.

Деятельность актуализирует отношение общества, психологическое содержание процессов общения. И только такой смысл отделяет общение от взаимодействия (интеракции).

Современная наука несет в себе настолько большое количество несовместимых или противоречивых определений и условий - это сильно усложняет исследование и применение на практике элементов общения. Умение общаться является главным критерием эффективной работы по достижению целей в жизни.

$$
* * *
$$

1. Бурмистрова, Е. В. Детская возрастная психология // Вестник практической психологии образования. 2014. - №4. - C. $41-44$

2. Герасина, Е. В. Детская психология. - М.: Владос, 2010

\section{Глухова Е.В. \\ Особенности воспитания и образованияобучающихся в социокультурной среде Абхазии \\ Российский государственный профессионально-педагогический университет (Россия, Екатеринбург)}

doi: 10.18411/lj-30-06-2017-45

idsp: 000001:lj-30-06-2017-45

Актуальность данной статьи обусловлена необходимостью выявления аспектов воспитания и обучения детей в абхазской семье. Исследование дает возможность сравнительного анализа народов Абхазии и России, основываясь на толерантном подходе.

Говоря о воспитании и обучении детей в абхазской семье, мы говорим прежде всего о тех аспектах, которые не совсем привычны для семей средней полосы России. Основой воспитания и обучения становятся традиционные устои. С самого раннего возраста обучение ведется на двух языках: русском и абхазском, что создает дополнительные трудности для ребенка, но в то же время развивает гибкость мышления и кругозор. Таким образом, можно выделить билингвизм (двуязычие) как одну из особенностей обучения и воспитания ребенка. Также необходимо отметить, что как устная, так и письменная речь на двух языках развита в одинаковой степени и к моменту поступления в школу, ребенок свободно владеет ими. Небольшой особенностью является особый местный акцент, неправильное употребление окончаний и падежей, что исправляется в процессе обучения в школе. Интересным фактом является разговор на двух языках одновременно как в процессе обучения, так и в бытовой среде, то есть начало предложения может быть на русском языке, а окончание на абхазском и наоборот. При этом, отсутствуют какие-либо разделения для облегчения усвоения двух языков одновременно, а именно: не применяется разделение языков по сферам (например, про 
одежду говорим только на абхазском языке, а про пищу-на русском), гендерное разделение также отсутствует (например, мама говорит на русском, а отец-на абхазском). Важным фактором является то, что ребенок, разговаривая на двух языках одновременно, не чувствует себя оторванным от социума, не имеет нужды ставить психологические барьеры, а в подростковом возрасте не чувствует себя ущербным, так как билингвизмобычное явление для Абхазии. У ребенка существуют партнеры по общению-сверстники, учителя, родители, которые не только дают возможность слышать различные варианты языков, конструкции предложений, манеру произношения, то и поддерживают ребенка психологически.

При поступлениив школу, обучение ведется на двух языках, при этом у родителей есть возможность выбрать, в каком именно классе необходимо обучение: с углубленным изучением русского или абхазского языка. Кроме этого, в школе существует и привычное для нас разделение на математическое и гуманитарное направление обучения.

Еще одной особенностью при воспитании ребенка является почитание старшего поколения. В одном доме могут проживать несколько семей, включая бабушек и дедушек. Такой культ определенным образом связан с религией. Согласно верованием абхазцев все живое является носителем души. Такое убеждение, как и упомянутый выше культ предков, есть часть автохтонной религии или, как ее еще называют, «индигенная религия». Автохтонная религия (от греч. «туземный, коренной»)- религиозные верования и ритуалы, возникшие в этнической среде без внешнего инорелигиозного влияния и развившиеся на основе свойственных группе этнических особенностей [1]. В воспитании детей культ предков является одной из самых главных особенностей.

Но несмотря на то,что современное образование в Абхазии тесно связано с культурными особенностями, огромное влияние оказывает российская образовательная система. После завершения грузино-абхазской войны в 1993 году, Абхазия приняла решение о переходе на Российские образовательные стандарты. Образовательные учреждения Абхазии разделяются на начальные, средние и неполные средние. Неполные средние школы находятся в основном в небольших населенных пунктах.

В Сухуме, столице республики, действуют пара частных общеобразовательных школ. Есть лицей и интернаты при средних школах. Но выпускники окончившие школу без дополнительной подготовки не могут поступить в высшие учебные учреждения в России. Для развития системы образования и выведения ее на современный уровень выполняются следующие контрольные задачи: внедрение единых образовательных стандартов для всех учебных заведений республики,упорядочение системы отбора абхазских абитуриентов, поступающих в российские вузы по целевым направлениям, выполнение подписанного ранее Договора о союзничестве и стратегическом партнерстве между РА и РФ, а также создание и осуществление образовательных проектов на всех уровнях образования [3].

Такие стратегические методы позволят не только укрепить сотрудничество между Россией и Абхазией, а также повысить уровень и качество образования обучающихся, не вырывая их из социокультурного контекста что является основным и таким важным при рассмотрении системы образования Абхазской республики.

$$
* * *
$$

1. Горбунова, Е.В. Пути реализации концепции модернизации Российского образования на период до 2010 года [Текст] / Е.В. Горбунова // Образование и наука. Известия Уральского отделения Российской академии образования, № 4 (22). - 2003. - С. 118-121.

2. Дарвиш, О.Б. Возрастная психология [Текст] / О.Б. Дарвиш. - М. :Владос, 2005. - 264 с.

3. Культура веры. [Электронный ресурс] - Режим доступа: www.religiocivilis.ru(дата обращения: 19.06.2017)

4. Научно-исследовательский институт «Прометей» [Электронный ресурс]. - Режим доступа: http://old.mediaartlab.ru/db/inst.html?id=72 (дата обращения: 19.06.2017) 


\title{
Николаева К.В., Стороженко И.И., Федорин С.В. \\ Развитие и совершенствование выносливости у курсантов военно-медицинского вуза с применением тренажерных средств
}

\author{
Военно-медицинская академия им.С.М. Кирова
}

(Россия, Санкт-Петербург)

doi: $10.18411 / \mathrm{lj}-30-06-2017-46$

idsp: 000001:lj-30-06-2017-46

\section{Аннотация}

Специализация медицинского направления относится к типу «человек - человек» и требует от обучаемых интеллектуальных, физических, нервно-психических затрат, в том числе определенных профессионально важных качеств. Труд медицинских специалистов связан с большой ответственностью. Некоторые профессионально важные качества можно развить и повысить с помощью определенного тренировочного процесса на занятиях физической культурой.

Ключевые слова: физические качества, развитие выносливости, профессионально важные качества врача, устойчивость к утомлению, выносливость к эмоциональным и физическим нагрузкам, использование тренажерных средств.

\section{Abstract}

Specialization in the medical field is of type «man-man» and requires of the learners intellectual, physical, psychical costs, including certain professionally important qualities. The work of health care professionals is a big responsibility. Some professionally important qualities we can develop and improve through specific training process on physical education.

Keywords: physical quality, training of cadets medical, endurance training, professionally important qualities of the doctor, resistance to fatigue, endurance to emotional and physical stress, use of training AIDS.

Последние десятилетия научно-технический прогресс оказывает значительное влияние на общество в целом и на работающее население в частности. Число лиц, выполняющих в основном умственную работу (труд с преимущественным напряжением мыслительных процессов, управленческий труд, операторский труд, труд с высоким нервным напряжением, труд медицинских работников, в том числе и труд учащихся) увеличивается, в то время как число людей, занятых тяжелым физическим трудом, снижается.

Кроме регулярного нервно-психического напряжения к специфическим профессиональным факторам умственного труда следует отнести и гипокинезию, влияние которой на состояние организма невозможно переоценить. Использование технических средств, робототехники и других результатов современных открытий в жизнедеятельности человека влечет за собой снижение активности организма и наименьшее использование его биологических ресурсов, а объем информации в результате увеличения темпа работы, сферы общения с людьми и сферы обслуживания стремительно растет.

В настоящее время медицинская сфера не осталась нетронутой: развитие промышленной техники, автоматизация производства, внедрение автоматических систем управления меняют и характер производительного труда, что в свою очередь ведет к повышению специальных требований, предъявляемых к организму человека и к физической подготовленности будущего врача. То есть в основе физической подготовки курсантов-медиков к предстоящей трудовой деятельности - всестороннее физическое развитие. Это основа для совершенствования всех жизненно важных функций организма.

Так как особенности медицинского труда могут отрицательно влиять не только на состояние здоровья и снижать общую выносливость, то наиболее эффективным средством развития и совершенствования выносливости у будущих специалистов 
является приобщение их к физической культуре и спорту с учетом особенностей профессиональной деятельности - профессиональной прикладной физической подготовки с использованием тренажерных средств.

В результате контрольных проверок физической подготовленности курсантов выявлен недостаточно высокий уровень развития общей выносливости, а это физическое качество является наиболее важным для будущего специалиста медицинского профиля. Соответственно, профессионально важные качества для них необходимо развивать средствами и методами физической культуры в той степени, которая позволит им на самом высоком уровне выполнять обязанности по предназначению, что и легло в основу разработки данной методики.

Целью нашего исследования является теоретическое обоснование и разработка для курсантов-медиков экспериментальной методики по физической подготовке на основе развития и совершенствования выносливости с применением тренажерных средств.

В результате анализа профессиональной деятельности специалистов медицинского профиля и литературы, нами использованы различные средства и методы физической подготовки для развития профессионально важных качеств курсантов-медиков, в т. ч. и с применением тренажерных средств, однако работ, направленных на развитие и совершенствование выносливости у курсантов-медиков с применением тренажерных средств не обнаружено.

На основе полученных результатов разработан и экспериментально апробирован специальный комплекс упражнений, направленный на развитие и совершенствование выносливости у курсантов военно-медицинского вуза.

Период обучения курсантов совпадает с активным формированием духовных и физических качеств, с подготовкой к выполнению профессиональных функций. Проблема формирования двигательной активности будущих специалистов медицинской сферы имеет важное значение, поскольку с возрастом у человека все в большей степени проявляется гиподинамия, в т. ч. и у курсантов-медиков. Это обусловлено не только большим объемом аудиторных занятий, но и занятий, которые отводятся на самостоятельную работу, что, в свою очередь, способствует увеличению числа лиц с неудовлетворительным состоянием здоровья, предрасположенностью к частым заболеваниям, а значит недостаточно высоким уровнем развития физических качеств, особенно выносливости.

Физическое качество «Выносливость» определяют как важнейшее качество, которое проявляется и в профессиональной, и в спортивной, и даже в повседневной жизни людей регулярно и влияет на эффективное выполнение определенной деятельности за определенный интервал времени. Другими словами - это способность организма поддерживать необходимую для обеспечения профессиональной деятельности мощность нагрузки и противостоять утомлению, возникающему в процессе выполнения определенной работы.

Исходя из этого, в медицинской сфере чаще необходима специальная выносливость, например, статическая. Она связана с длительным нахождением тела в определенном положении в условиях сниженной подвижности, в т.ч. и в ограниченном пространстве. Необходима и специальная выносливость к продолжительной работе умеренной и малой мощности; к длительной работе переменной мощности и сенсорная выносливость. Последняя означает способность быстро и точно реагировать на внешние воздействия без снижения эффективности профессиональных действий, даже при условии утомления сенсорных систем. Сенсорная выносливость зависит от функционирования анализаторов, прежде всего: двигательного, зрительного, слухового, тактильного, вестибулярного.

В ходе систематических занятий физической культурой происходит адаптация организма к физическим нагрузкам, развитие физических качеств, в частности, общей выносливости, что, в свою очередь, способствует повышению умственной и физической работоспособности, которая является наиболее значимой для специалистов медицинской сферы. При развивающемся утомлении, либо в экстремальной ситуации или в условиях 
неблагоприятных воздействий внешней среды специалистам медицинского профиля особенно важно сохранять способность действовать с применением специальных навыков труда.

С целью увеличения времени работы с высокой эффективностью до появления признаков утомления был разработан специальный комплекс физических упражнений с использованием тренажерных средств, применение которого в период обучения курсантов-медиков позволяет сократить время адаптации организма к нагрузкам и одновременно с этим включает опережающее развитие и совершенствование уровня выносливости.

С использованием комплекса физических упражнений достигается повышение уровня устойчивости организма к неблагоприятным воздействиям внешней среды, а при регулярном использовании тренажерных средств, особенно в холодное время, достигается более высокий уровень физической подготовленности курсантов-медиков к предстоящим нагрузкам по предназначению. Это направление профессионально-прикладной физической подготовки повышает устойчивость организма курсантов-медиков и к неблагоприятным факторам окружающей среды, тем самым, отвечая предъявляемым специфическим требованиям избранной специализации.

В результате проведенного исследования определены выводы, которые подтверждают выдвинутую нами рабочую гипотезу исследования, в т.ч.:

1. Анализ специфики профессиональной деятельности специалистов медицинского профиля показал, что в настоящее время подготовка специалистов-медиков проводится в недостаточно полном объеме, в частности, без учета профессионально прикладной физической подготовки для этих специальностей. Используемые средства, методы и формы физической подготовки для развития профессионально важных качеств курсантов-медиков нуждаются в дополнениях, в т.ч. и со стороны разработанного специального комплекса физических упражнений с применением тренажерных средств.

2. Установлено, что специальный комплекс физических упражнений не требует дополнительной материальной базы по физической подготовке, а использует уже имеющиеся тренажерные средства, что повышает экономический эффект процесса обучения курсантов академии.

$$
\text { *** }
$$

1. Источник №1. Захаров Е.Н., Карасев А.В., Сафонов А.А. Энциклопедия физической подготовки (Методические основы развития физических качеств) / Под общей ред. А.В. Карасева. - М.: Лептос, 1994. $-368 \mathrm{c}$.

2. Источник №2. Лавриненко В.В. Развитие общей выносливости в короткие сроки для повышения профессиональной работоспособности курсантов окружных учебных центров. СПб. 2005. - 24 с.

3. Источник №3. Марищук В.Л. Психолого-педагогические аспекты физической подготовки. - Л.: ВДКИФК, 1985. - 5-10 с.

4. Источник №4. Навакатикян А.О., Крыжановская В.В. Возрастная работоспособность лиц умственного труда. Киев, 1979. - 208 с.

5. Источник№5. ТрековА.И. Методика совершенствования работоспособности курсантов вузов как средство повышения их военно- профессиональной готовности. / Дис. канд. пед. наук. Пермь. 2000. $24 \mathrm{c}$. 


\section{РАЗДЕЛ ХІV. ПСИХОЛОГИЯ}

\section{Бехтер А.Ю., Бутров Н.А., Хайров М.А. \\ Необходимость владения иностранным языком для будущих специалистов технического профиля}

Пензенский государственный университет

(Россия, Пенза)

doi: $10.18411 / \mathrm{j}-30-06-2017-47$

idsp: 000001:lj-30-06-2017-47

\section{Аннотация}

Изучение иностранного языка в неязыковом вузе в значительной степени способствует развитию профессионального и личностного саморазвития будущих специалистов. В процессе обучения иностранным языкам студенты неязыкового вуза отмечают рост интереса к своей специальности, что способствует формированию внутренней положительной мотивации на профессиональное становление, а значит и стимулом развития личности в целом.

специальности.

Ключевые слова: неязыковой вуз, иностранный язык, технические

В современном обществе нельзя не заметить возрастание значимости знания иностранного языка, в особенности английского, так как он насчитывает порядка 840 миллионов носителей (для 340 из которых он является родным). Китайский язык, например, насчитывает около 1,2 миллиарда носителей, но он не слишком распространен за пределами своей страны. Исходя из информации о распространенности можно сделать вывод, что знание английского языка открывает новые возможности, такие как доступ к новой информации, перспективы устройства на работу за границей, путешествия так же станут более комфортными. Нельзя забывать и о технической важности данного языка, часть программных сред и оболочек для них сделаны на английском языке без возможности перевода на русский.

В современных условиях вопрос конкурентоспособности российского образования, его эффективности и ключевой роли в развитии страны является очень важным. Требования рынка труда к квалификации выпускника также заметно возросли. Подготовка конкурентоспособного работника в любой области труда не должна сводиться только к обеспечению высокого уровня его профессиональной компетенции. Специалист должен получить также и социальную подготовку, которая осуществляется посредством обществоведческих и гуманитарных дисциплин. В настоящее время работодатель, в условиях обостряющейся конкуренции, предъявляет свои требования, которые зачастую выходят за рамки образовательных стандартов. Одним из таких требований является владение одним или несколькими иностранными языками. Получение качественного языкового образования расширяет возможности трудоустройства выпускников технических вузов, участия в международных программах и продолжения обучения за рубежом, а также повышает их конкурентоспособность на рынке труда.

Вся жизнь людей, как она видится на протяжении тысячелетий, - это накопление опыта и передача его следующим поколениям. Каждое новое поколение овладевает накопленным опытом, учится пользоваться им. И само вносит в общую копилку знаний и умений новые сведения, полученные в течение всей жизни. Поэтому обучение всегда было одной из основных забот людей. Появление компьютеров с их широкими возможностями обработки и поиска информации, отображения ее в удобной для человека форме натолкнули исследователей на идею компьютерного обучения. Появление таких систем открыло эру автоматизированных обучающих систем (АОC). АОС содержат базу 
знаний об изучаемом объекте, специальные средства для выдачи информации ученику и контроль за уровнем усвоения знаний. В развитых АОС имеются специальные средства для тестирования обучаемого и подбора для него наилучшей стратегии обучения. Основу любого автоматизированного рабочего места составляет персональная электронновычислительная машина в сочетании с устройством отображения информации. Кроме того, в зависимости от вида деятельности специалиста на том или ином АРМ в состав его оборудования могут входить средства телефонной и радиосвязи (АРМ диспетчера), комплекс измерительных приборов, анализаторов и т.п. (АРМ исследователя), приборы контроля и автоматической регистрации параметров технологических процессов (АРМ технолога), комплекс автоматизированных устройств и инструментов (АРМ монтажника микроэлектронных приборов) и т.д. Например, на рабочем месте конструктора установлена ЭВМ с набором устройств хранения, обработки, регистрации и отображения графической и символьной информации, облегчающих расчет и оптимизацию формы проектируемой детали, поиск унифицированных и нормализованных примеров из соответствующих справочных банков данных. На автоматизированном рабочем месте инженер быстрее сможет подготовить рабочую документацию. Работа конструктора на AРМ построена в режиме диалога с машиной, что позволяет быстро делать исправления в документах и одновременно выдавать исходную информацию для технолога.

Рабочее место технолога тоже автоматизировано. С помощью ЭВМ он разрабатывает практически весь технологический процесс. ЭВМ составляет программу обработки, в которой предусмотрены форма и размеры заготовки. Основываясь на конструкторской документации, ЭВМ выбирает обрабатывающий элемент и т.П. При правильном использовании автоматических рабочих мест производительность труда технолога повышается в десять и более раз. Наряду с распечатанным описанием технологического процесса технолог получает управляющую программу для обрабатывающей машины, например станка с числовым программным управлением.

Для нас, как для будущих инженеров необходимы знания о достижениях науки и техники, отечественного и зарубежного опыта в сфере организации производства. Решение подобных задач невозможно без анализа зарубежных публикаций и обмена информацией на иностранном языке, общения на форумах с зарубежными партнерами; составления и перевода технической документации с описанием функционирования и технического обслуживания различных устройств. Например, для специалиста в области информатики и программирования знание иностранного языка очень важно. Различные программы создаются на иностранном языке, так как фирмы часто заключают договоры с иностранными инвесторами. И чтобы работать с программой, надо знать иностранный язык. Изучение иностранного языка - это уже первая ступень для более углубленного изучения языка программирования и для большего профессионализма в области информатики. При переводах знание языка помогает избегать малейших ошибок и неточностей, а это может помешать дальнейшей работе или привести к сбою в системе. Так же сегодня предлагается много технической информационной литературы, в которой без знания языка не так просто разобраться или вообще практически невозможно. Знание иностранного языка увеличивает возможность продвижения по карьерной лестнице. Некоторые фирмы посылают молодых специалистов в другие страны для повышения квалификации. Увеличивает круг общения со специалистами в той или иной области не только с англичанами, но и с другими странами, ибо английский язык является международным. К тому же есть возможности работать или дальнейшего обучения в других странах, а не только командировочные поездки по специальности.

Изучение иностранного языка также призвано обеспечить развитие комплекса общекультурных и общенаучных компетенций, включая: воспитание толерантности и уважения к духовным ценностям разных стран и народов; развитие информационной культуры; расширение кругозора и повышение общей культуры студентов и т.д. 
И в заключении необходимо отметить, что на сегодняшний день, говоря о высококвалифицированном специалисте, мы отмечаем не только его (специалиста) узконаправленные профессиональные качества, но это ещё и специалист со знанием иностранного языка.

\section{Щербаков Д.В., Степанов А.Н., Токарева Г.М. \\ Клинико-социальные и психопатологические характеристики психически больных с криминальным и нормосообразным поведением}

Государственное бюджетное учреждение здравоохранения Московской области «Центральная клиническая психиатрическая больница»

(Россия, Москва)

doi: $10.18411 / \mathrm{lj}-30-06-2017-48$

idsp: 000001:lj-30-06-2017-48

\section{Аннотация}

В статье представлены результаты сравнительного анализа клинических, социальных и психопатологических характеристик психически больных с криминальным и нормосообразным поведением.В изучаемых группах пациентов обнаружены статистически значимые различия в осознаваемой пациентами негативно-личностной симптоматике, при этом различия по продуктивно-психотической симптоматике не выявлены.Представленная информация может быть использована в судебнопсихиатрической практике при составлении программ психологической реабилитации лиц с психическими расстройствами, совершавшими общественно опасные деяния.

Ключевые слова: психически больные, общественно опасные деяния, характеристики лиц с психическими расстройствами.

\section{Abstract}

Results of the comparative analysis of clinical, social and psychopathological characteristics mentally sick with criminal and holes-mosoobraznym behavior are presented in article. In the studied groups of patients statistically significant distinctions in the negative and personal symptomatology realized by patients are found, at the same time distinctions on productive and psychotic symptomatology are not revealed. The provided information can be used in forensic-psychiatric practice by drawing up programs of psychological recovery of persons with the mental frustration making socially dangerous acts.

Keywords: mentally sick, socially dangerous acts, characteristics of persons with mental disturbances.

\section{Введение}

Важным аспектом научного анализа в судебной психиатрии является изучение комплекса факторов, влияющих на формированиепротивоправного поведения лиц, страдающих психическими расстройствами (Дмитриева Т.Б., 2000; Шостакович Б.В., 2001; Казаковцев Б.А., 2001; Мальцева М.М., Котов В.П., 2005; Кондратьев Ф.В., 2006; Усов Г.М., 2008 и др.).

Многие судебные психиатры отмечают высокий риск совершениялицами, имеющими психические расстройства, опасных деяний, нередко связанных с насилием, а такжесообщают о значительных показателях их повторности (Ипатов М.Ю., 2000; Осколкова С.Н., 2005; Кондратьев Ф.В., 2006; Усюкина М.В. 2006; Дмитриева Т.Б. и др., 2009).

Еще в 1994 году Карпов А.С. сообщал о высокой частоте правонарушений, совершаемых психически больными: от $1 \%$ до $20 \%$ по отдельным видам преступлений (Карпов А.С., 1994). В дальнейшем в России одновременно с общим ростом преступности отмечался рост правонарушений среди психически больных (Дмитриева Т.Б. 1997, 2000).

Согласно статистическим данным, в 2005 году на 1000 зарегистрированных психически больных 12,9\% совершили общественно опасные деяния (ООД), в связи с чем 
были направлены на СПЭ, а в 2015 году этот показатель увеличился и составил 19,8\% случаев (самый высокий показательза последние 10 лет) [5].

На этом фоне сохраняется актуальность совершенствования методов профилактики общественно опасных действий лиц, страдающих психическими расстройствами (Морозов Г.В., Шостакович Б.В., 1987; Мальцева М.М., Котов В.П., 1995; Дмитриева Т.Е., Шостакович Б.В., 1999, 2002; Макушкин Е.В. 2013; Ткаченко А.А. 2013).В связи с этим дальнейшее изучение особенностей пациентов, совершавших и не совершавших правонарушения, является необходимым для выявления характеристик, оказывающих влияние на противоправное поведение $[1,2,3,4]$.

Нами было проведено исследование, целью которого являлось выделениев ходе сравнительного анализа клинических, социально-демографических и психопатологических характеристик, а также субъективных представлений о наличии негативно-личностной и продуктивно-психотической симптоматики $\mathrm{y}$ лиц $\mathrm{c}$ психическими расстройствами, совершавших и не совершавших ООД.

\section{Материал и методы исследования.}

Было обследовано 126 психически больных мужчин в возрасте от 19 до 67 лет, представляющих две группы: первую группу составили 92 пациента, совершавших ООД, вторую группу - 34 пациента, не совершавших правонарушения. В каждой группе 50\% обследованных имели диагноз F20-F21 и 50\% диагноз F06-F07.

В карте обследования пациента фиксировались клинические, социальнодемографические и психопатологические переменные, субъективные представления о наличии негативно-личностной и продуктивно-психотической симптоматики. Использовались данные из медицинской карты амбулаторного больного форма 25/y-04 и медицинской карты стационарного больного форма 003/y. Статистическая обработка материала проводилась с использованием пакета прикладных программ Statistica 20.0. Для оценки достоверности различий в выборках применялся критерий Манна-Уитни, для определения значимых различий в частоте встречаемости явления анализировались таблицы сопряженности.

\section{Анализ результатов исследования.}

Для определения клинических, социально-демографических, психопатологических характеристик лиц, совершавших и не совершавших ООД, был проведен анализ таблиц сопряженности, который показал следующее.

Пациентов, совершивших ООД, по сравнению с пациентами, не совершавшими правонарушения, значимо отличают такие особенности социальных взаимоотношений как конфликтные отношения с отцом в детском возрасте ( $\square \square \square, 705, \mathrm{p}=0,017$ ) и частые конфликты со сверстниками ( $\square \square \square 8,798, \mathrm{p}=0,003$ ). Пациенты, совершившие ООД, значимо чаще во время учебы в школе пропускали занятия, имели плохую успеваемость $(\square \square \square 5,23, \mathrm{p}=0,022)$, школу не окончили $(\square \square \square 3,999, \mathrm{p}=0,046)$. Во взрослом возрасте отмечается проявление агрессии на родственников $(\square \square \square 13,252, \mathrm{p}=0,000)$ или на ближнее окружение ( $\square \square \square 4,014$, p=0,045).

Психопатологические особенности пациентов, совершивших правонарушения, достоверно чаще проявляются в виде отягощенной алкоголизмом наследственности родственников ( $\square \square \square 3,966, \mathrm{p}=0,046)$, нарушением сна в детском возрасте ( $\square \square \square 4,454$, $\mathrm{p}=0,035)$ и наличием диагноза «Синдром гиперактивности с дефицитом внимания» ( $\square \square \square$ 5,076, $\mathrm{p}=0,02) 4$ Во взрослом возрасте - эпизодической алкоголизацией $(\square \square \square 4,441$, $\mathrm{p}=0,035)$, злоупотреблением алкоголем ( $\square \square 7,665, \mathrm{p}=0,006)$, наличием инвалидности по психическому заболеванию ( $\square \square 4,640, \mathrm{p}=0,031)$.

Лица, совершившие правонарушения, по сравнению с лицами, не совершавшими ООД, значимо чаще имеют две и более госпитализаций в психиатрический стационар ( $\square \square \square 6,247$, p=0,012), принимают психотропные препараты ( $\square \square \square 3,962, \mathrm{p}=0,047$ ). Для них чаще характерен быстропрогредиентный характер течения заболевания с частыми обострениями ( $\square \square \square 3,797, \mathrm{p}=0,051)$.

В группе лиц, не совершавших ООД, по сравнению с лицами, совершившими правонарушения, значимо больше лиц, имевших среднюю успеваемость в школе 
( $\square \square \square 12,519$, p=0,000), работающих в коммерческих структурах ( $\square \square \square 12,799$, p=0,000), сферах здравоохранения, культуры и образования $(\square \square \square 10,111, \quad \mathrm{p}=0,001)$ по высококвалифицированным профессиям ( $\square \square \square 4,308, \mathrm{p}=0,038)$.

Социальные взаимоотношения лиц, не совершавших ООД, значимо чаще характеризуются тесными, эмоционально теплыми отношениями в детстве с отцом $(\square \square \square 6,898, \mathrm{p}=0,009)$, во взрослом возрасте отсутствием в их поведении агрессии по отношению к окружающим ( $\square \square 28,379, \mathrm{p}=0,000)$, частым общением с родственниками при хороших отношениях с ними $(\square \square \square 9,858, \mathrm{p}=0,002)$.

В группе пациентов, не совершавших ООД, значимо больше лиц, которые не проходят лечение у врача психиатра и не получают психотерапевтическое лечение $(\square \square \square 14,859$, $\mathrm{p}=0,000)$, один раз госпитализировались в психиатрический стационар $(\square \square \square 18,173, \mathrm{p}=0,000)$.

С целью сравнения данных, полученных при изучении субъективных представлений о наличии негативно-личностной и продуктивно-психотической симптоматики у лиц, совершавших ООД и не совершавших правонарушения, был проведен частотный анализ.

В результате проведения дескриптивного анализавсего массива полученных данных выявляется, что большинство пациентов, совершивших правонарушения, считают себя малоэмоциональными (60\%) и не обидчивыми (61\%), в то же время, среди пациентов, не совершавших правонарушения, выделяют у себя данные характеристики $38 \%$ и $47 \%$ обследованных, соответственно.

Полагают, что они несклонны делиться своими переживаниями, $70 \%$ лиц с криминальным анамнезом и 46\% лиц без криминального анамнеза. Из числа обследованных, совершивших правонарушения, 33\% отмечают, что с трудом собираются с силами, чтобы начать что-то делать, в то же время из пациентов, не совершавших ООД, на наличие у них данных особенностей указывают 53\% обследованных, соответственно.

О периодических ощущениях печали, уныния и беспомощности заявляют $50 \%$ лиц, совершавших ООД, и $32 \%$ лиц, не совершавших правонарушения. Приступы сильного страха отмечают $32 \%$ лиц с криминальным анамнезом и $20 \%$ без криминального анамнеза.

Оценивая особенности социальных взаимоотношений, полагают, что окружающие относятся к ним враждебно и недоброжелательно $21 \%$ пациентов, совершавших ООД, и $15 \%$ пациентов, не совершавших правонарушения.

Заявляют о наличии у них нарушений внимания в виде повышенной отвлекаемости 53\% лиц, совершивших ООД, и $33 \%$ лиц, не совершавших правонарушения, о невнимательности по отношению к окружающим - 44\% и 32\% пациентов, соответственно. При этом, 34\% представителей первой группы отмечают у себя снижение реакции на окружающих, даже на громкие звуки, но только 12\% обследованных, относящихся ко второй группе, сообщают о наличии у себя данных проявлений.

Заявляют о том, что способны воспринимать то, чего не видят и не слышат другие люди, 28\% пациентов, совершавших ООД, и 18\% не совершавших ООД. О наличии навязчивых и фантастических мыслей, которые кажутся нереальными, сообщают, соответственно, $65 \%$ и $38 \%$ пациентов, совершавших ООД, а также $54 \%$ и $26 \%$ пациентов, не совершавших правонарушения.

При сравнении полученных описательных статистик и выделении значимо отличающих группы характеристик использовался критерий U-Mann-Whitney. В изучаемых группах пациентов обнаружены статистически значимые различия восознаваемой пациентами негативно-личностнойсимптоматике. Различия по продуктивно-психотической симптоматике не выявлены.

\section{Заключение}

Таким образом, проведение сравнительного анализа полученных данных позволило выявить статистически значимые различия в клинических, социальных и патопсихологических характеристиках, а также субъективных представлениях о наличии 
негативно-личностной и продуктивно-психотической симптоматики упсихически больныхс криминальным и нормосообразным поведением.

Пациентов, совершавших ООД, значимо отличают от лиц, не совершавших правонарушения, проявления социальной дезадаптации, начиная с детского возраста, в виде конфликтных отношений с отцом и частых конфликтов со сверстниками. Во взрослом возрасте - в виде проявления агрессии на родственников или на ближнее окружение.

Для них характерны большое количество экзогений, синдром гиперактивности с дефицитом внимания в детстве, а во взрослом возрасте - эпизодическая алкоголизация или злоупотребление алкоголем.

У лиц, совершавших ООД, достоверно чаще отсутствует динамика течения психического заболевания, для них характерны частые обострения психического заболевания и резистентность к психотерапевтическим воздействиям, несмотря на частую госпитализацию в психиатрическую больницу. Они чаще являются инвалидами по психическому заболеванию, отличаются неадекватно-позитивным восприятием субъективного качества жизни.

В отличии от лиц, совершавших правонарушения, в группе пациентов, не совершавших ООД, значимо больше лиц, имеющих более высокий трудовой статус, уровень академической успеваемости и социальной адаптации. Они реже обращаются к врачу-психиатру, имеют минимальное количество госпитализаций в психиатрической стационар.

Пациенты, совершавшие ООД, чаще, чем пациенты, не совершавшие правонарушения, отмечают у себя следующие негативно-личностные проявления: снижение эмоциональности, нарушение абстрактного мышления, эмоциональную отгороженность.

Пациенты без криминального анамнеза чаще, чем пациенты, совершавшие правонарушения, сообщают о повышенной отвлекаемости и пассивно-апатической социальной отгороженности (ощущение печали, уныния и беспомощности, необходимость собраться с силами, чтобы приступить к деятельности).

$$
\text { *** }
$$

1. Булыгина В.Г. Психологическая концепция профилактики общественно опасных действий лиц с тяжелыми психическими расстройствами: Автореф. дис... д-ра. мед. наук. - М., 2015. - С.4-5.

2. Казаковцев Б.А., Малкин Д.А., Букреев Н.В., Булыгина В.Г. Совершенствование деятельности психиатрических больниц специализированного типа с интенсивным наблюдением // Психическое здоровье. - 2011. - № 5. - С. 3-31.

3. Котов В.П., Шишков С.Н., Полубинская С.В. и др. Современное состояние законодательного регулирования порядка исполнения предусмотренных уголовным кодексом принудительных мер медицинского характера в отношении лиц с тяжелыми психическими расстройствами // Психическое здоровье. - 2013. - Т. 11. - № 7 (86). - С. 3-15.

4. Макушкина О.А., Голланд В.Б., Яхимович Л.А. Значение мер медицинского характера в системе профилактики общественно опасных действий психически больных // Российский психиатрический журнал. - 2013. - № 4. - С. 20-26.

5. Мохонько А.Р., Макушкин Е.В., Муганцева Л.А. Основные показатели деятельности судебнопсихиатрической экспертной службы Российской Федерации в 2015 году: Аналитический обзор. - М., 2016. - С. 17. 


\section{РАЗДЕЛ ХУ. СЕЛЬСКОЕ ХОЗЯЙСТВО}

\section{Басиев С.С., Джиоева Ц.Г., Плиева 3.Я., Басиева А.С., Царикаев 3.А. Роль зеленых удобрений в семеноводстве картофеля}

Горский государственный аграрный университет

(Россия, Владикавказ)

doi: $10.18411 / \mathrm{j}-30-06-2017-49$

idsp: 000001:lj-30-06-2017-49

\section{Аннотация}

Выявлена продуктивность и качество семенных и продовольственных клубней перспективных, районированных и новых сортов картофеля зарубежной и отечественной селекции в зависимости от экологических условий их выращивания и применения сидеральных культур.

Ключевые слова: картофель, семеноводство, сидераты.

В настоящее время вопросами применения зеленых удобрений занимаются научные учреждения, которые рекомендуют для использования на сидерацию в самостоятельных и промежуточных посевах большой набор культур: из бобовых многолетний и однолетний люпин, сераделлу, донник, озимую и яровую вику, горох посевной и полевой, астрагал, чину, клевер, чечевицу, эспарцет, сою; из злаковых озимую рожь, райграс однолетний и многолетний; из крестоцветных - горчицу, озимый и яровой рапс, озимую сурепицу, масличную редьку и др. Разлагаясь и поставляя в почву не гумифицированное органическое вещество, сидеральные культуры обогащают пахотный слой лабильными формами органического вещества. Зеленые удобрения улучшают агрегатный состав почвы и повышают водопрочность ее структуры $[1,2,3,4]$.

Для изучения сидеральных культур в биологическом земледелии закладывали опыт с 8 сортами картофеля (Волжанин, Владикавказский, Предгорный, Невский, Удача, Жуковский ранний, Романо и Сантэ) с использованием сидеральных культур: горчицы, редьки масличной и рапса на фоне N30P30K30. Экспериментальную работу проводили в 2005-2009 гг. на бурых лесных оподзоленных почвах Юго-Осетинской республики. Общая площадь делянки - 72,0 м2, учетная - 60,0 м2. Размещение вариантов рендомизированное. Повторность опыта - четырехкратная. Предшественник сидеральные культуры. Глубина посадки 8-10 см. Посадку проводили клубнями средней фракции (60-65 г) густотой 48,0 тыс. клубней на 1 га.

Все учеты и наблюдения проводили по методикам ВНИИКХ (1967; 1994; 2008; 2010; 2012), ВИР (2010) и Доспехова Б.А. (1985) [5].

Многочисленные исследования показали тесную взаимосвязь количества органического вещества, оставляемого предшествующей культурой, с содержанием агрономически ценной структурой. По многолетним травам количество агрегатов $0,25 \ldots 10$ мм увеличилось по сравнению с повторным посевом кукурузы на зерно на 9,5\%, по озимому рапсу - на 5,8\%, а на сидеральном посеве озимого рапса - на 19,2\%. Средняя плотность почвы по многолетним травам была в пределах от 1,06 до 1,16, при сидерации -1,05-1,19, тогда как на контроле 1,08-1,21 г/см3.

Одним из основных показателей ценности сидеральных культур, влияющих на плодородие почвы, является масса органического вещества, накопленного в наземных и подземных органах растений ко времени запашки. Наши исследования показали, что она сильно варьировала в зависимости от возделываемой культуры и погодных условий. В среднем за несколько лет исследований больше органического вещества было накоплено 
(7,97; 6,64; 6,13 т/га) такими культурами, как рапс, редька масличная и горчица соответственно.

Данные наших исследований свидетельствуют, что сидеральные культуры оказывают существенное влияние на урожай клубней картофеля, максимальный показатель которого отмечен по всем сортам на варианте с использованием горчицы на сидерат с применением фона удобрений. Высокий урожай накопили сорта Владикавказский - 30,9 т/га, Удача - 29,6 т/га, Жуковский ранний 28,4 т/га.

Сидеральные культуры способствуют не только накоплению органических остатков в почве, её оструктуриванию, росту урожайности, но и увеличению крахмалистости и содержанию сухих веществ в клубнях различных сортов картофеля (на 0,4-3,4\%) с максимумом по сорту Предгорный. Довольно высокие показатели отмечены и по сортам Романо, Сантэ и Владикавказский.

\section{Выводы}

1. Максимальные показатели по разложению надземной биомассы и корневых остатков отмечено на варианте, где картофель использовался в качестве монокультуры (78\%), минимальные - при запашке редьки масличной $(75 \%)$.

2. Выявлена эффективность использования сидеральных культур, повышающих содержание в почве минеральных веществ: азота, фосфора, калия, - и, как следствие, позволяющих увеличить массу клубней картофеля в пределах 5-10 т/га.

\section{$* * *$}

1. Басиев, С.С. Сидеральные культуры - повышение плодородия почвы и урожая картофеля / С.С. Басиев // Земледелие. - №1. - 2008. - С. 33.

2. Басиева, Л.Ж. Влияние различных звеньев севооборота на плодородие и продуктивность выщелоченного чернозема с близким залеганием галечника / Л.Ж. Басиева // Автореферат на соискание ученой степени кандидата сельскохозяйственных наук. - Владикавказ, 2000. - 22 с.

3. Доева, Л.Ю. Влияние сидерации, внесения соломы и азотных удобрений на урожай клубней картофеля / Доева Л.Ю., Бзиков М.А., Мамиев Д.М. // Иформационный листок СО ЦНТИ. - №99. - 1999.

4. Kumar, M. Influence of potato cultivars and $\mathrm{N}$ leveets on contribution of organic amendments to N nutrition / Kumar M., Trehan S.P. // J.Indian Potato Assn. - 2012. - Vol. 39. - N. 2. - P. 133-144.

5. Доспехов, Б.А. Методика полевого опыта / Б.А. Доспехов. - М., 1985. - 352 с. 


\title{
РАЗДЕЛ ХVІ. АРХИТЕКТУРА
}

\author{
Данилов Д.С. \\ Новые средства производства в архитектуре \\ Саратовский Государственный Технический Университет имени Гагарина Ю.А.
} (Россия, Саратов)

doi: $10.18411 / \mathrm{j}-30-06-2017-50$

idsp: 000001:lj-30-06-2017-50

\section{Аннотация}

Процесс создания архитектурной формы разделён на два этапа: проектирование и производство. Соответственно этим этапам можно разделить средства, которые использует архитектор для решения задач на средства проектирования и средства производства. Средства производства являются одним из оснований архитектурной практики. Существует ряд архитектурных стилей, для которых появление новых средств производства имеет исключительно важное значение.

Ключевые слова: архитектура, архитектурный стиль, развитие архитектуры, средства производства, ЧПУ, параметризм

Процесс создания архитектурной формы разделён на два этапа: проектирование и производство. Соответственно этим этапам можно разделить средства, которые использует архитектор для решения задач на средства проектирования и средства производства.

Средства производства в архитектуре зависят в первую очередь от уровня развития техники. Долгий период развития новых средств производства сопряжен с большими масштабами архитектурных сооружений. Ещё большее время требуется для того, чтобы новые средства производства распространились повсеместно. В других областях дизайна новые средства производства начинают использоваться гораздо раньше и для архитекторов дизайн становится в некотором роде полигоном, на котором отрабатываются механизмы использования новых технологий.

Средства проектирования и средства производства ограничивают и обуславливают друг друга, например, без соответствующих средств производства некоторые средства проектирования могут быть неприменимы, возможна и обратная ситуация.

Не каждый сдвиг в области техники отражается на архитектуре, однако в ряде случаев такая взаимосвязь существует,нас же в первую очередь интересует кардинальные сдвиги в области техники, влияющие на формирование архитектурных стилей.Существует ряд стилей, для которых появление новых средств проектирования или производства имеют исключительно важное значение.

Итак, на протяжении рассматриваемого периода можно выделить три основныепарадигмы в сфере производства: доиндустриальная модель - большое разнообразие в малых количествах, индустриальная (фордистская) модель - малое разнообразие в больших количествах, постиндустриальная (пост-фордистская) модель большое разнообразие в больших количествах.

C начала истории западноевропейской архитектуры до начала индустриальной цивилизации средства производства развивались по курсу совершенствования способов обработки материала.Сравнив производство романской архитектуры, и, например, архитектуры эпохи классицизма мы не увидим принципиальной разницы, за исключением уровня обработки материалов и совершенства строительных конструкции. Последнее скорее связано с развитием инженерной мысли, чем с совершенствованием средств производства. До начала двадцатого века тип производства в архитектуре не изменялся доиндустриальная модель - единичное или серийное производство.

Первым действительно важным переломным моментом можно считать индустриальную революцию в технике. С началом ХХв. появился принципиально новая парадигма в технике - массовое производство. Парадигма массового производства стала определяющей для всей эпохи, в том числе и для архитектуры модернизма. Идея 
массового производства - это не просто тип производственных отношений, это парадигма мышления. Для общества в целом идея массового производства выразилась через идею «общества всеобщего благоденствия», для архитектуры в модернизме.Факторы, определяемые, логикой самой модели производства вызвали необходимость разработки типовых конструктивных решений, начиная с дверной ручки и заканчивая градостроительным уровнем. Рациональная сторона архитектуры выражена в архитектуре модернизма в абсолютной форме. Новый метод производства, типовые предварительно изготовленные конструкции, новые строительные материалы - всё это послужило отправной точкой для архитектуры первой половины двадцатого столетия.

Средства производства не привязаны к какому-то конкретному стилю, но одновременно с этим могут направлять развитие стиля, задавать определённые рамки формообразования. Так модель массового производства не является тем, что определяет все стороны архитектуры модернизма. Ничто не мешает применить средства массового производства к другим стилям. Во второй половине - конце ХХв. модель массового производства занимала доминирующую позицию и продолжала обслуживать архитектуру постмодернизма не менее успешно, чем архитектуру модернизма. Однако несомненно, что модернизм не стал бы тем, что он есть без парадигмы массового производства.

Следующий переломный момент в развитии технологий - переход от фордистской модели производства к пост-фордистской. Коротко суть этого перехода можно описать так: вместо массового производства одинаковых изделий, массовое производства индивидуальных изделий. Конечно этот процесс не был спонтанным, можно сказать, что он начался практически сразу после зарождения фордизма.

Ярким примером перехода от индустриальной модели производства к постиндустриальной является сам проект Генри Форда - модель «Т». Спустя 19 лет после того как его автомобиль завоевал рынок, его концепция всё же исчерпала себя и в 1927 году его самый популярный автомобиль был снят с производства. Несмотря на все плюсы модели Т, она перестала устраивать потребителя, особенно если учесть, что автомобиль в течении 10 лет выпускалась только в чёрном цвете. Спустя время появился более широкий спектр предложений, и касательно всего сегмента автомобильной промышленности, и разнообразия модельного ряда внутри отдельного предприятия. Идея «общества всеобщего благоденствия» даже на этом примере показывает свою несостоятельность. Удешевление предметов промышленного производства, сокращение цикла потребления товаров, разнообразие дизайна - признаки постиндустриального общества и следствие перехода к пост-фордистской модели производства.

В рамках естественной эволюции индустриальной модели производства, технологии становятся всё более гибкими. В архитектуре мы можем проследить тот же процесс, архитектура постмодернизма является началом перехода от индустриальной модели производства к постиндустриальной. В архитектуре этот период отражается, помимо прочего, в большей вариативности форм.

Первые предпосылки пост-фодрдистской модели появились задолго до двадцатого века. В 1804 году был изобретён ткацкий станок с возможностью перепрограммирования с помощью перфокарт, такой станок можно считать праотцом современных станков с ЧПУ (Числовое Программное Управление). Однако до появления компьютеров, такие станки были эффективны только в полмеры, их перепрограммирование было слишком трудоёмким. Но «цифровая революция» снабдила уже давно существовавший инструмент новым, гибким средством программирования. Компьютер являясь новым средством проектирования в архитектуре, стал также основой нового средства производства.

Относительно воздействия на архитектуру переход к постфордистской модели не менее грандиозен, чем переход к фордистской. Если перенос архитектуры модернизма на доиндустриальную модель производства ещё можно представить, то с параметрической архитектурой это просто невозможно. Параметризм - новейший архитектурный стиль, провозглашённый Патриком Шумахером, идеи параметризма наиболее полно раскрыты в его основном труде "The Autopoiesisofarchitecture" [1,2].Новые технологии производства были недостающим звеном для возникновения параметрической архитектуры, как только этот пробел был закрыт цифровые авангардные эксперименты перешли в область реального строительства. Благодаря совершенствованию станков с ЧПУ и появлению гибкого средства их программирования, новым средствам параметрического 
проектирования, CAD и BIM системам, новая модель производства практически полностью сформировалась в архитектуре. Для архитектуры это выражается, например, в том, что воплощение какой-либо конструкции из уникальных элементов, не отразится ни на удорожании и усложнении производства (на предприятии работающего в рамках постфордистской парадигмы), ни на усложнении сборки. Такая модель производства даёт архитектору широчайший спектр, ранее недоступных, возможностей со стороны формообразования, возможностей реализации наиболее подходящих форм вне зависимости от их сложности. Воплощение эстетических принципов нового стиля было бы просто невозможным, или крайне нецелесообразным, без соответствующих средств производства, среди которых с некоторыми условностями можно выделить следующие виды:

Станки с ЧПУтакие станки существуют уже не один десяток лет, но ранее не существовало достаточно гибкого средства их программирования. Область применения станков с ЧПУ в строительстве: раскрой различных типов материала, Зд-фрезеровка, изготовления матриц и т.д. Такие станки позволяют создавать оболочки любой сложности, из плоских или криволинейных элементов, так же активно используются при созданиипредметов дизайна.

ЗД принтерыуже начинают, в качестве эксперимента, применятся в строительстве. Это мощнейший инструмент производства, который несомненно будет широко применятся в архитектуре. ЗД принтеры позволяют создавать формы любой сложности. В последнее время появляются крупномасштабные Зд принтеры способные печать здания, ведутся разработкив области печати несколькими материалами разными по свойствам (например, материалы по-разному работающие на растяжение и сжатие), разработки в области печати металлом, что необходимо в архитектуре. Для наступления эры 3Д принтеров нужны новые достижения в области строительной химии, но принтеры ужесейчас появятся на строительных площадках.

Робототехника - универсальный инструмент производства, сфера применения которого ограничена лишь фантазией и экономической целесообразностью, от производства до финишной доработки изделий и сборки. Роботов применяют при изготовлении сложных форм, при покраске, полировке, сварке и т.д. Архитекторы взяли на вооружение промышленных роботов, которые использовались ранее, например, в области автомобилестроения. Сфера применения промышленных роботов постоянно расширяется благодаря большой гибкости их использования. Многие передовые архитекторы и университеты активно экспериментируют с применением таких роботов.

Существует ещё множество инструментов, которые призваны решать частные задачи производства, здесьони не были указаны ввиду их узкой специализации. Новые средства производства открывают перед архитектором широчайшие возможности в области формообразования. Новый архитектурный стиль - параметризм, полностью основан на новых инструментах производства и проектирования, и без них невозможен.

1. Schumacher, P. The Autopoiesis of architecture, vol.1, A new framework for architecture. [Аутопоэзисархитектуры.T.1.] United Kingdom, London: Willey \& Sons. 2011 - 498c.

2. Schumacher, P. The Autopoiesis of architecture, vol.2, A new agenda for architecture. [Аутопоэзисархитектуры.T.2.] United Kingdom, London: Willey \& Sons. 2012 - 715c.

Дергунов С.А., Кулешов И.В., Кутлюк А.Б. Создание логистических систем в дорожном строительстве

Оренбургский государственный университет (Россия, Оренбург)

doi: 10.18411/lj-30-06-2017-51

idsp: 000001:lj-30-06-2017-51

\section{Аннотация}

В статье рассматриваются основы принципы строительства автомагистралей, на основе логистического подхода и ее практического применения. 
Ключевые слова: логистика, дорожное строительство, эффективность, логистический бизнес-процесс.

В настоящее время дорожная сеть общего пользования Российской Федерации по своим количественным и качественным характеристикам далеко не в полной мере отвечает требованиям автомобильного транспорта. Около половины федеральных дорог требуют ремонта, более $40 \%$ нуждаются в усилении дорожной одежды, около $20 \%$ - в улучшении состояния покрытия. Состояние почти 40\% федеральных дорог оценивается как неудовлетворительное. Технический уровень состояния местных дорог также чрезвычайно низок. По оценкам специалистов, для удовлетворения потребностей экономики в автомобильных перевозках протяженность автодорог общего пользования следует увеличить, по крайней мере, в 2,5 раза, в основном за счет развития местной дорожной сети. Сложившийся за годы реформ механизм принятия инвестиционных решений в отрасли несовершенен. В последнее время как заказчик, так и непосредственные исполнители работ - подрядчики, фактически отказались от планирования дорожных работ. Это приводит к нерациональному выбору объектов строительства и неэффективному использованию ресурсов. Для совершенствования методов принятия инвестиционных решений в дорожном строительстве требуется поиск новых подходов к планированию и организации много проектной деятельности дорожностроительных фирм. С учетом отраслевых особенностей дорожного строительства наиболее эффективным может стать логистический подход.

В современной практике дорожного строительства управление материальными ресурсами зачастую осуществляется на основании общеупотребимых, но далеко не всегда эффективных и прогрессивных методов управления транспортными, погрузоразгрузочными и другими операциями, являющимися неотъемлемой частью материального обеспечения технологических процессов строительства. Бизнес-процессы снабжения в сфере производства работ в таком случае формируются исключительно под воздействием производственных требований и не учитывают принципы экономической эффективности. Как следствие такого отношения к системе управления ресурсами, в деятельности дорожно-строительной организации на каждом этапе процесса материального снабжения возникают дополнительные затраты, которых можно было бы избежать. С учетом того, что строительство автомобильной дороги занимает длительный период времени, в течение которого осуществляется значительное количество бизнеспроцессов, связанных с материальным снабжением (от выбора поставщика до операций с материалами на участке производства работ), даже незначительные дополнительные затраты каждого бизнес-процесса по объекту выливаются в существенные потери денежных средств. Такого рода неосмотрительность может оказать в будущем существенное влияние на финансовое состояние организации и её конкурентоспособность.

В настоящее время решение проблем разработки новых форм организации строительства объектов на основе современных методов управления становится важной и актуальной задачей. Организация процесса снабжения объектов дорожного строительства необходимыми материальными ресурсами заключается в формировании рациональной системы взаимозависимых элементов, каждый из которых должен максимальным образом обеспечивать не только возможность бесперебойного осуществления технологических процессов строительства, но и максимальное удобство применения. При этом элементы должны функционировать эффективно не только по отдельности, но и вместе, формируя сложную взаимосвязанную структуру, оказывающую, в конечном счете, влияние не только на деятельность ответственных подразделений, но и на всю организацию в целом.

Повышение эффективности деятельности организации может достигаться за счет формирования в дорожных организациях логистической системы. Такая система должна обеспечивать необходимый уровень гибкости и адаптивности, так как внешняя среда дорожной организации динамична и оказывает существенное влияние на показатели её деятельности. Логистическая система также должна быть способна подстраиваться под изменяющиеся требования внутренней среды, полностью удовлетворяя требованиям всех производственных подразделений. С другой стороны, логистическая система должна 
быть достаточно устойчивой, чтобы не подвергаться деструктивному влиянию множества факторов, оказывающих воздействие на процессы материально-технического снабжения в отрасли.

Для формирования логистической системы, удовлетворяющей этим требованиям необходимо провести логистический анализ сферы строительства. Можно выделить следующие задачи логистического анализа сферы строительства:

- выявление логистических резервов, включая резервы оптимизации экономических потоков, резервы сопряжения технологий резервы управления запасами;

- оценка логистического потенциала каждого участника процесса строительства;

- установление возможности сопряжения экономических интересов участников логистических цепей и систем;

- выработка прикладных организационно-технических и социальноэкономических мероприятий по логистизации сферы строительства.

Одним из ключевых элементов такого подхода является оптимизация логистических бизнес-процессов. Логистический бизнес-процесс в дорожном строительстве - это упорядоченная последовательность действий, в результате которой посредством управляющего воздействия осуществляется преобразование входных ресурсов процесса в результат, определяемый логистическими целями.

Ключевым свойством логистического бизнес-процесса является то, что это логически взаимосвязанная совокупность действий, определяемая отношениями, возможностями, ограничениями и ресурсами внутри конечного множества субъектов и объектов, объединяющихся в систему с целью получения конкретного результата, отчуждаемого или потребляемого самой системой. Внутри логистических бизнеспроцессов выделяются подпроцессы, которые, в свою очередь состоят из подпроцессов меньшего порядка и так до уровня, на котором дальнейшая детализация процессов не будет иметь смысла. В рамках одного объекта совокупность этих процессов образует единый укрупненный логистический бизнес-процесс.

Однако строительство одновременно нескольких объектов силами одной строительной организации требует координации и взаимоувязки нескольких объектных систем. В этом случае формируется строительный поток, в основе которого лежит совокупность нескольких объектных потоков, образующих межобъектный процесс. Преобладающие в нем связи, естественно, ресурсные, обусловленные необходимостью рационального распределения ресурсов (как материальных, так и энергетических, и трудовых) между различными объектами в соответствующие периоды времени. Такое усложнение делает необходимым контроль за оптимизацией и рационализацией не только бизнес-процесса в рамках конкретного объекта, но и в их совокупности и взаимосвязи в каждый отдельный момент времени.

Дорожное строительство является одной из отраслей, обладающих наиболее ярко выраженными особенностями, оказывающими влияние на все процессы организации и управления. Отраслевые особенности дорожного строительства, связанные, прежде всего, с технологической спецификой производства работ, предъявляют ряд требований к организации логистических бизнес-процессов на предприятиях, делающих их узкоспециализированными и направленными на удовлетворение логистических потребностей конкретной отрасли.

Если объектом изучения принимать все сферы деятельности дорожной организации, бизнес-процессы в ней в зависимости от характера деятельности и отношению к строящемуся объекту делятся на основные (операционные), управляющие и вспомогательные. Операционные бизнес-процессы являются фундаментом основной деятельности, остальные бизнес-процессы либо оказывают управленческие воздействие на основные, либо служат для их поддержания и обслуживания. Применительно к логистическим же процессам, мнения ученых разделились. Так, одни относят всю совокупность логистических бизнес-процессов к основным, другие ученые к основным бизнес-процессам относят только процессы внутрипроизводственной логистики, а бизнеспроцессы заготовительной, информационной и прочих видов логистики - к 
вспомогательным. Так или иначе, одной из основных задач логистизации дорожного строительства является их оптимизация.

Оптимизация логистических бизнес-процессов в традиционном понимании призвана решить ряд задач. Во-первых, это сокращение времени осуществления операции в согласовании с темпом продвижения потока строительства и с учетом тех случаев, когда сокращение времени невозможно или нерационально и может повлиять на технологические характеристики строящегося объекта (к особым случаям относят, прежде всего, операции с горячими асфальтобетонными смесями). Во-вторых, это минимизация затрат, связанных как с оперативными манипуляциями с материальными ресурсами на всем пути перемещения материального потока (межобъектного или в рамках одного объекта), так и с управлением этими процессами. Причем такая экономия включает в себя не только затраты на закупку, транспортировку, складирование, погрузоразгрузочные работы, но и экономию трудовых ресурсов и производственных мощностей непосредственно на месте производства работ.

Поэтому прежде чем формировать логистическую систему, необходимо определить критерий, учитывающий комплексный характер требований.

В настоящий момент для внедрения в практику деятельности дорожных предприятий инструментария логистики и построения логистических систем необходимо устранить различного рода барьеры, мешающие логистизации дорожно-строительной отрасли.

$$
* * *
$$

1. Логистика в России: новые пути раскрытия потенциала. М.Волков.

2. Экономика дорожного строительства: учеб. Пос.: в 2 ч. Ч. 2. Гавриш В.В.

3. Экономическое обоснование программы развития сети автомобильных дорог. // Экономика строительства, №3, 1999 г. С.28-33. Беляков Г.С.

4. Экономико - математические методы в строительстве. Методические указания. Изд. Мордовский унт Саранск 2006. 36c.

5. Развитие логистики в строительстве: особенности, перспективы, методы принятия решений. Плетнева Н.Г., Власова Н.В.

\title{
Диль Н.В. \\ Эко проектирование высотных зданий и сооружений
}

\author{
АСА ДГТУ \\ (Россия, Ростов-на-Дону)
}

doi: $10.18411 / \mathrm{lj}-30-06-2017-52$

idsp: 000001:lj-30-06-2017-52

При проектировании и строительстве высотных зданий и сооружений решаются множество проблем. Одной из таких является экологическое строительство. В последние годы этому вопросу стали уделять больше внимания. Это связанно с ухудшением экологических характеристик городов, с потребностью уменьшения энергопотребления и с использованием некачественных строительных материалов, которые выделяют вредные вещества.

Экологическое строительство- это возведение сооружений при котором процесс проектирования, строительства и эксплуатации минимально воздействует на окружающую среду. Можно выделить основные принципы при эко-проектировании высотных зданий:

- Снижение энергопотребления.

На снижение энергопотребления могут влиять такие факторы как правильная ориентация здания по сторонам света, использование нетрадиционных возобновляемых источников энергии (энергии солнца, воды, ветра, земли).

- Применение природных возобновляемых материалов.

Природные материалы имеют множество преимуществ перед искусственными. Например, не выделяют летучие вещества, которые опасны для здоровья человека. И к тому же обладают высокой теплопроводностью. 
- Снижение уровня загрязнения окружающей среды.

Эта проблема занимает не мало важное место в проектировании высотных зданий и сооружений. К примеру, может происходить загрязнение строительным мусором поверхностных и подземных вод. Поэтому необходимо предусмотреть специальные препятствующие мероприятия.

- Использование современного инженерного оборудования.

Современные инженерные системы создают комфортные условия для человека, который находится в высотном здании. Еще одним из преимуществ является, что они сокращают расходы на энергопотребление.

Существуют компании, которые оценивают эко-эффективность строительных объектов. Одной из таких является британская- BREEAM. Её критерии оценки считаются одними из самых строгих. Более чем 90\% сооружений, сертифицированных BREEAM, находятся в Великобритании. В России этот сертификат получили 60 объектов. Следующий стандарт, который оценивает эко-эффективность LEED. Она обосновалась в Америке. В России по этой системе выдано 12 сертификатов. Существует компания, которая адаптирована для российского строительства-GreenZoom. B её основе лежат те же принципы оценки, что в двух предыдущих. Преимуществом GreenZoom является доступность.

Из зарубежного опыта строительства экологических высотных зданий и сооружений можно отметить Hearst Tower (Башня Херст). Высота этого сооружения составляет 182 метра. Небоскрёб построен в Нью-Йорке на Манхеттене в 2006 году, архитектор Норман Фостер.

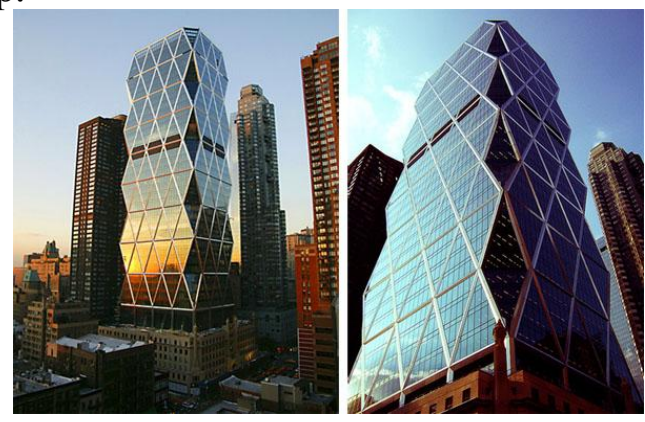

Этому сооружению присвоен золотой сертификат LEED. Это первый небоскрёб в Нью-Йорке где используется экологические нововведения. К примеру, на крыше установлена система которая собирает дождевую воду. Далее эта вода стекает по трубам в резервуар в подвал. Её используют для фонтанов и полива растений. Небоскрёб имеет систему энергосбережения. Основа её заключается в предельном потреблении солнечного света днём. Так же установлены электродатчики регулирующие включение и выключение освещения в помещениях. Около 90\% металлических конструкций, которые использовались при строительстве Hearst Tower содержат переработанные материалы, к тому же они не токсичны и безопасны.Атриум построен из известняка. Он обладает высокой теплопроводностью, что позволяет снижать энергопотребление.

Ещё одним из примеров может послужить башня Pearl River Tower (Жемчужная река). Небоскрёб построен в 2011 году в Китае в городе Гуанчжоу. Высота сооружения 310 метров.
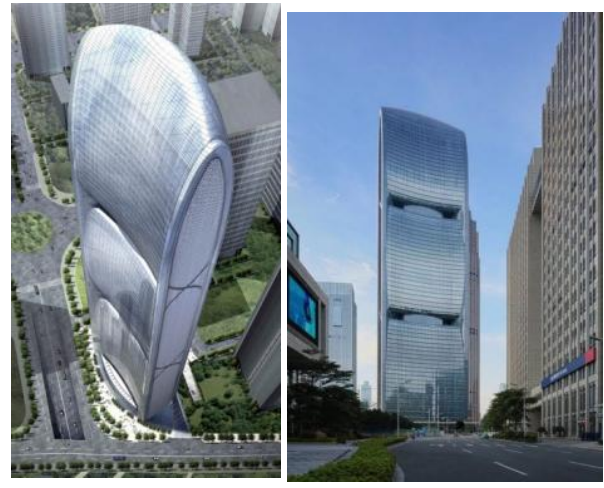
Проект выполнен архитекторами фирмы SOM. B Pearl River Tower смонтированы внутри ветровые турбины, это способствует тому, что сооружение расходует примерно на $60 \%$ меньше энергии чем ему подобные.

В здании установлены специальные окна, они скапливают солнечную энергию и оберегают сооружение от перегрева. В свою очередь жалюзи автоматически поворачиваются под углом исходя от солнечного света, это обеспечивает оптимальное освещение в течении всего дня. На крыше расположили устройства для сбора ливневой воды. Она течёт по трубам, которые расположены в полу, что создаёт условия для быстрого кондиционирования воздуха в помещениях.

Россия только делает первые шаги к проектированию высотных экологических сооружений. Одним из примеров является «Башня Федерации». Она построена в Москве в комплексе «Москва-Сити» в 2016 году. Архитекторы проекта Сергей Чобан и Пётр Швегер. Это сооружение состоит из двух башен, которые установлены на одном основании. Высота башни «Восток» 374 метра, башни «Запад» 242 метра. Основание представляет собой шестиэтажный атриум. Остекление, которое применено при строительстве защищает от ультрафиолета и потери тепла.
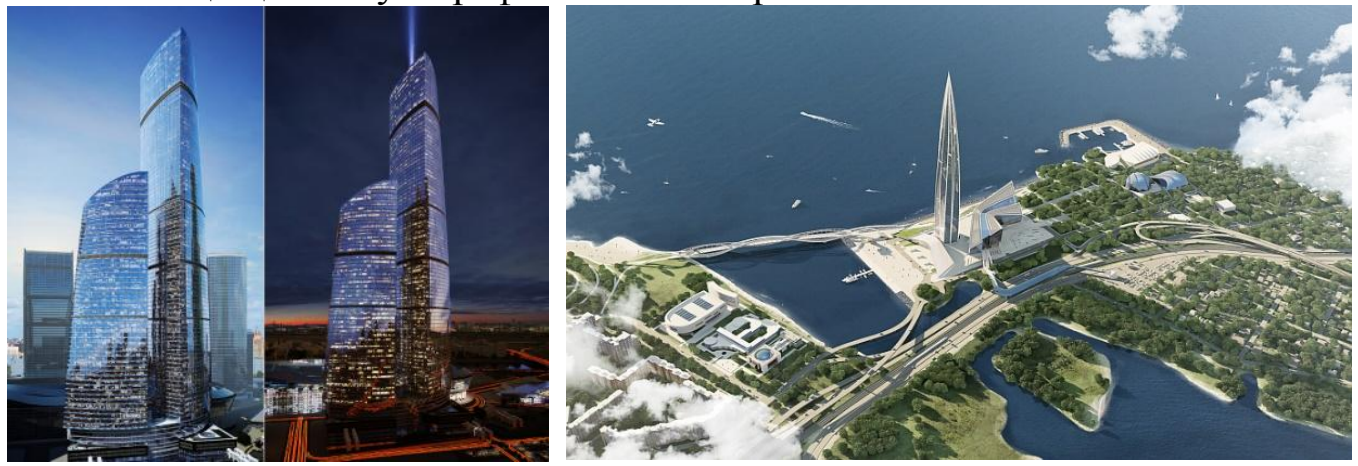

В небоскрёбе установлено современное оборудование, которое может перемещать излишки тепла и холода из одного помещения в другое. Так же здесь применяется система рекуперации тепла. Эта технология позволяет повторно использовать тепло для подогрева приточного воздуха.

В качестве нереализованного примера эко-проектирования можно взять проект «Лахта центр». Это 462 метровая башня, которая построится в Санкт-Петербурге в 2018 году. Архитектор Филипп Никандаров, инженер Николай Перин.

В проекте используется двойное остекление, что создаёт теплоизолирующий слой. Это позволяет повысить энергосбережение. Избыточное тепло при работе техники будет использоваться для обогрева помещений. Так же в башне будут установлены датчики присутствия для экономии воды и электроэнергии. Будут размещены специальные жалюзи, которые меняют угол поворота в зависимости от солнечного света, что даёт автоматически регулировать уровень освещенности в помещениях.

Предусмотрено применение очищенной ливневой воды для полива. Озеленённые стены и кровля будут обеспечивать дополнительное поступление кислорода. При строительстве «Лахта центр» применены экологичные материалы и материалы вторичной переработки.

Интерес к проектированию экологических высотных зданий и сооружений вызван в целях экономического сбережения, улучшения условий окружающей среды и жизни человека. Поэтому необходимо внедрять все принципы «зелёного строительства».

$$
* * *
$$

1. Особенности проектирования высотных зданий. Генералов В.П. 2009

2. Основы экологической архитектуры. Казанцев П.А. 2009

3. Проектирование современных высотных зданий. СюйПэйфу, Фу Сюеи, Ван Цуйкунь, СяоЦунчжэнь. 2008

4. Экологическое проектирование и экспертиза. Питулько В.М., Иванова В.В.

5. http://lakhta.center/ru/about/arch/

6. http://www.expo-mos.ru/projects/buildgreen.htm

7. https://www.rmnt.ru/story/realty/367711.htm 


\section{LJOURNAL.RU}

Научное издание

\section{Тенденции развития науки и образования}

Сборник научных трудов, по материалам

XXVII международной научно-практической конференции

30 июня 2017 г.

Часть 3

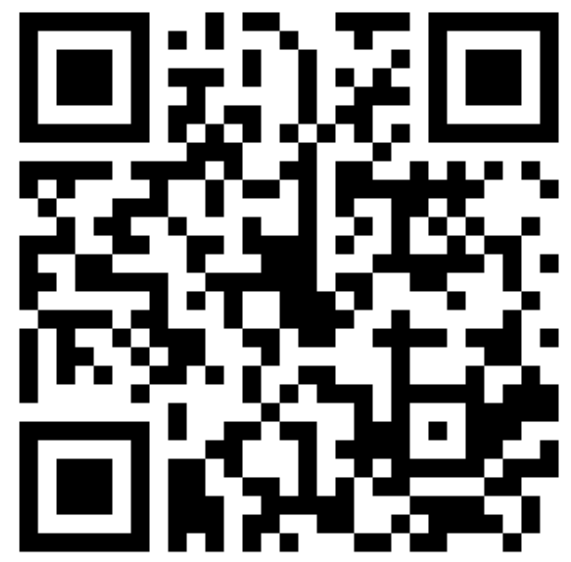

SPLN 001-000001-0161-LJ

Подписано в печать 23.07.2017. Тираж 400 экз.

Формат.60х841/16. Объем уч.-изд. Л 2.99

Бумага офсетная. Печать оперативная.

Отпечатано в типографии НИЦ «Л-Журнал»

Главный редактор: Иванов Владислав Вячеславович 